\title{
معوقات الحج إلى بيت الله الحرام في العصور الاسلامية
}

د.انتصار عدنان العواد

جامعة البصرة ـ كلية الآداب
ا.د جواد كاظم النصرالله

جامعة البصرة ـ كلية الآداب

ملخص البحث

دأب المسلمون على أداء طقوس الحج منذ نشريعه في زمن النبي محمد صلى الله عليه وآله وسلم، وكان المسلمون يبذلون جهودا مضنية في سبيل أداء مناسكه.

ومع هذا الاهتمام الثديد من لدن المسلمين، فإن هناك أسبابا حالت أحيانا دون أداء مناسك الحج لأفراد أو لأبناء مدينة أو دولة معينة، أو حالت كليا دون أداء مناسك الحج لذلك العام.

ويمكن تقسيم هذه الأسباب إلى ثلاثة عوامل: أولها: العوامل الفكرية، كدور المشركون في منع النبي محمد (ص) والمسلمين من أداءه، وما اتخذته القرامطة من أعمال حالت دون أداء مناسك الحج لسنين عدة.

ثم العوامل السياسية المتمثلة بدور السلطة الحاكمة، والاضطرابات السياسية في الدولة، وأعمال القبائل العربية إبان ضعف الدولة، حيث تقطع الطريق وتقوم بأعمال السلب والنهب للحجاج، فضلا عن سبطرة القوى الأجنبية على العديد من الدول والمدن الإسلامية. وهناك العوامل الطبيعية كالسيول والرياح العاتية، والزلازل والصواعق، والأوبئة، وغلاء الأسعار . 
يعد الحج إلى الأماكن المقدة من أهم الممارسات والطقوس عند مختلف الثرائع، ومنها الثريعة الإسلامية، فقد دأب المسلمون على أداء طقوس الحج منذ تنريعه في زمن النبي محمد صلى اله عليه وآله الها

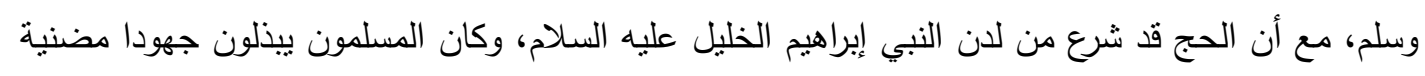

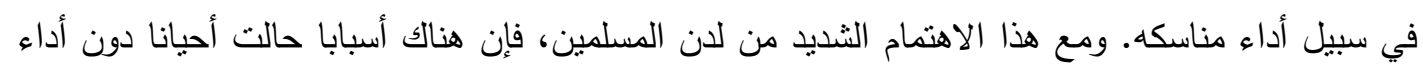

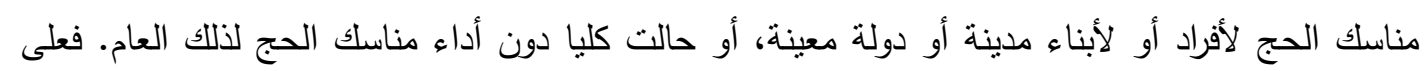

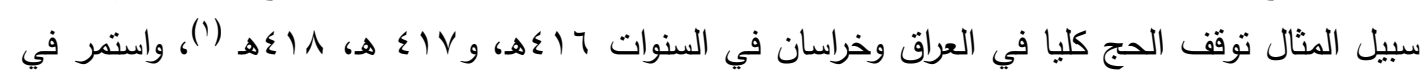

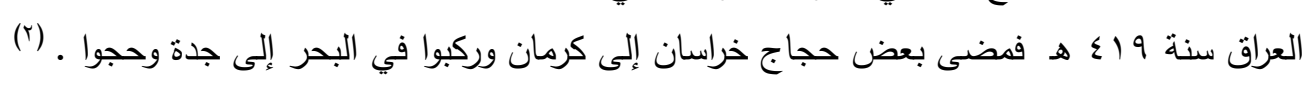

لقد أولى المؤرخون والرحالة أحداث الحج أهمية كبيرة، فسطروا في مؤلفاتهم الكثير مما يتعلق بمسيرة

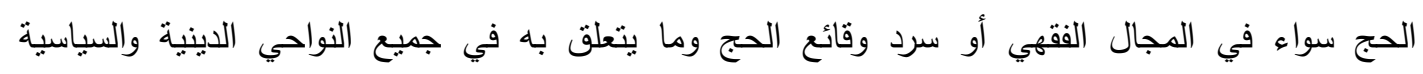

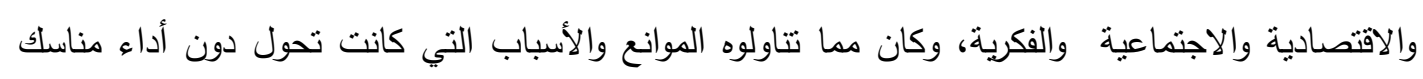
الحج إلى بيت الله الحرام.

ويمكن تقسيم هذه الموانع إلى أقسام ثلاث وهي الفكرية، والسياسية، والكوارث الطبيعية، ويندرج تحت

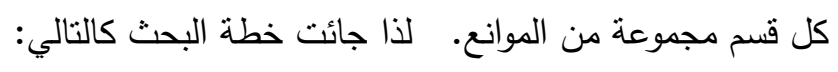

$$
\begin{aligned}
& \text { المبحث الأول: الاتجاهات الفكرية : } \\
& \text { ثانيا: القرامطة } \\
& \text { أولا: المشركون } \\
& \text { المبحث الثاني: العامل السياسي : } \\
& \text { ثانيا: الاضطرابات السياسية } \\
& \text { رابعا: سيطرة القوى الاجنبية } \\
& \text { أولا: دور الحكام المسلمين العان العين } \\
& \text { ثالثا: الأعراب } \\
& \text { المبحث الثالث: الكوارث الطبيعية }
\end{aligned}
$$




\section{المبحث الأول}

\section{الاتجاهات الفكرية}

أولا: المشركون:

كان الدين الأول لجزيرة العرب هو دين التوحيد الذي بذره النبي إبراهيم الخليل (ع) وولده النبي

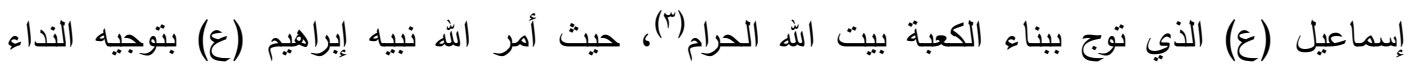

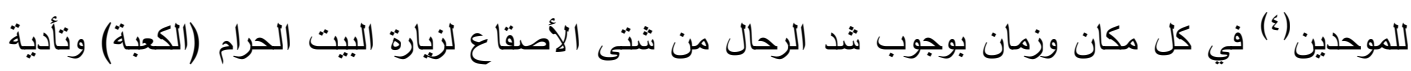

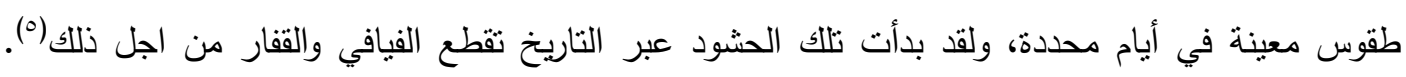

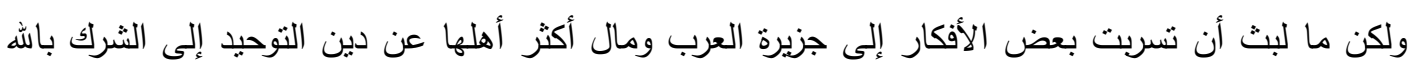

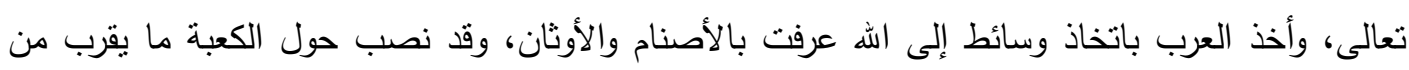

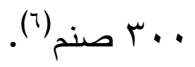

ولما بعث النبي محمد (صلى الله عليه وآله وسلم) ودعا قومه إلى نبذ عبادة الأصنام والرجوع إلى الى التى

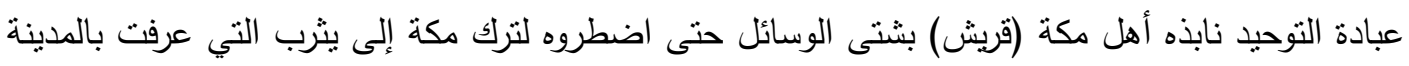

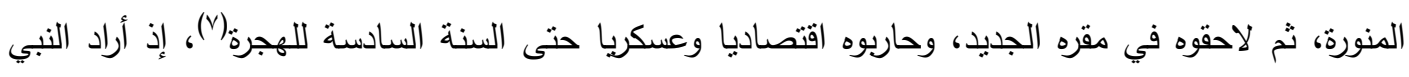

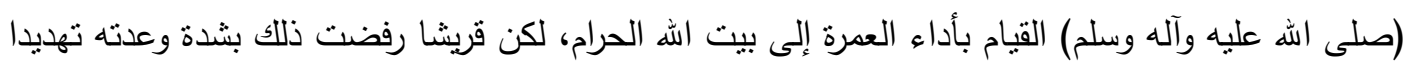
لها، مما أدى إلى عقد صلح عرف بصلح الحديبية()، كان من بنوده عودة المسلمين في هذا العام عن أداء لهاء

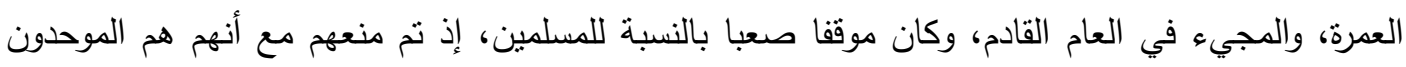

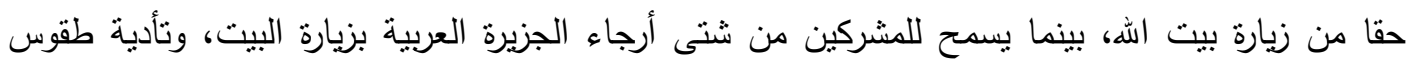

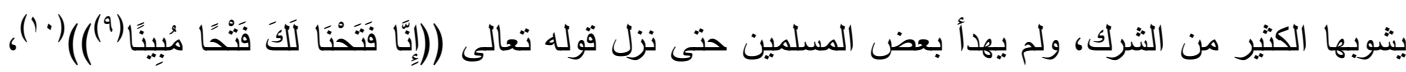

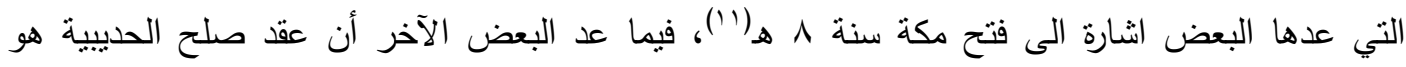

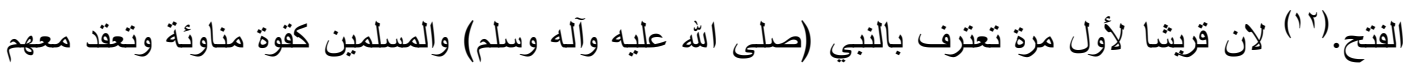

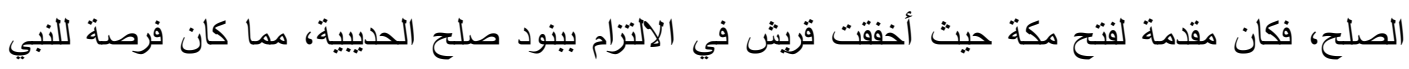

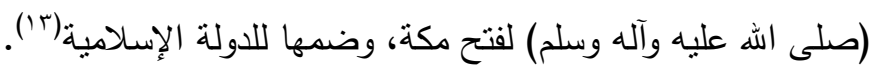


لعب القرامطة(؛) دورا سلبيا كبيرا سواء في موسم الحج بشكل عام أو مع الحجاج في مكة أو في

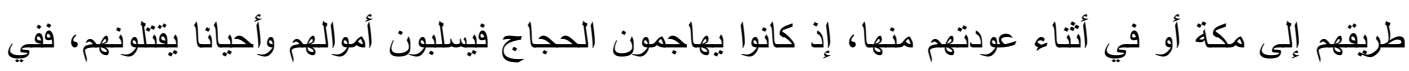

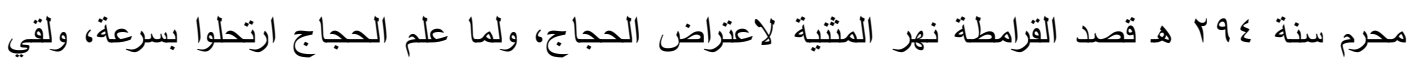

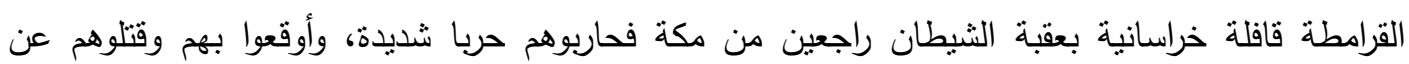

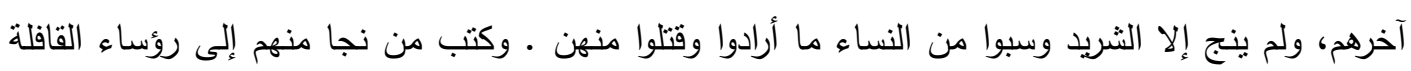

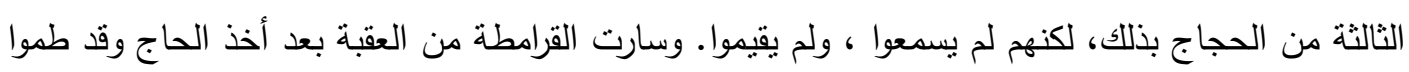

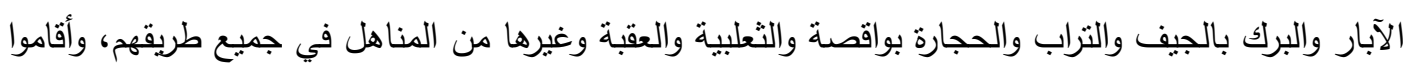

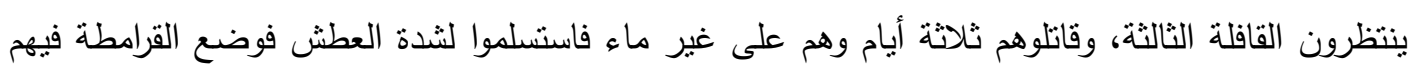

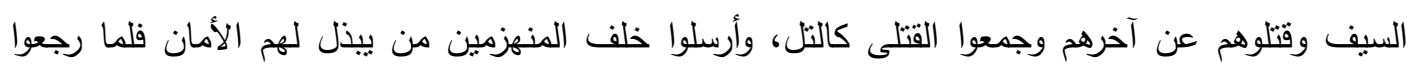

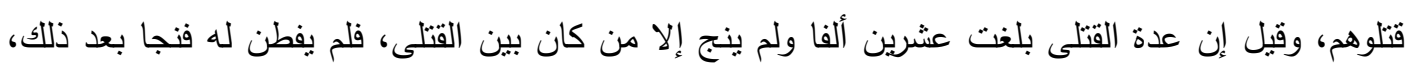

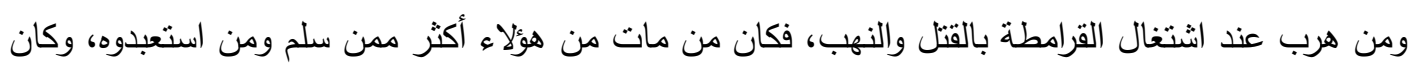

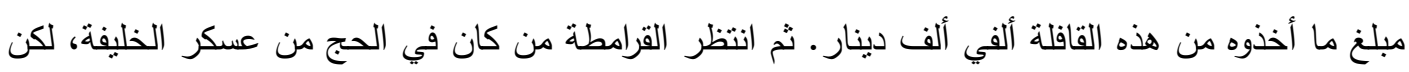

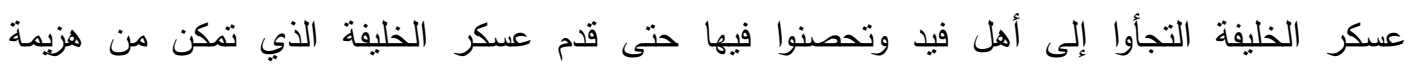
القرامطة. (10)

وفي سنة ا •r هـ تولى أمر القرامطة أبو طاهر (T') بن أبي سعيد(1)، الذي قطع طريق الحاج

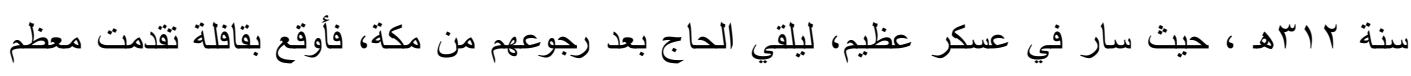

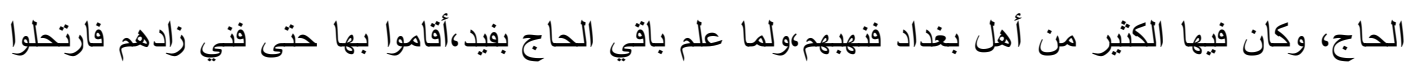

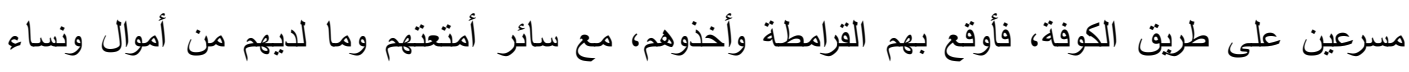

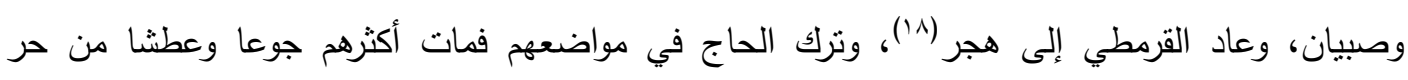

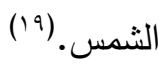

ثم أن أبا طاهر القرمطي أطلق سراح الأسرى وكتب للمقتدر يطلب منه البصرة والأهواز، فلم يوافق

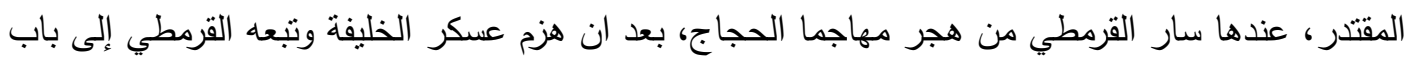
الكوفة فقاتلهم فانهزم عسكر الخليفة وهرب الباقون والحجاج من الكوفة ودخلها أبو طاهر وأقام ستة أيام 
بظاهر الكوفة يدخل البلد نهارا فيقيم في الجامع إلى الليل ثم يخرج يبيت في عسكره وحمل منها ما قدر على دلى

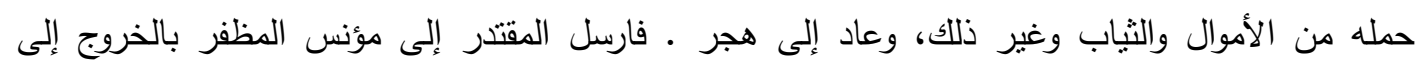

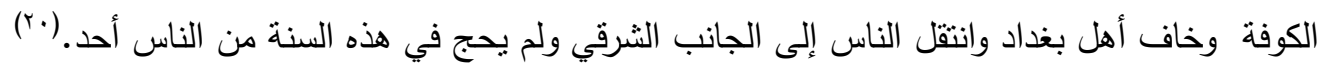

وفي سنة باس هـ اعترض القرامطة الحاج بزبالة. فقاتلهم أصحاب الخليفة فانهزموا ووضع القرامطة

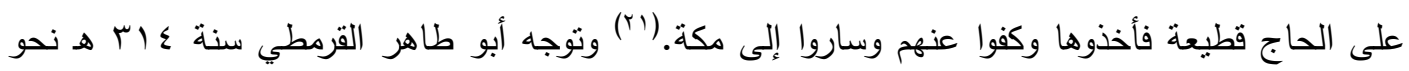

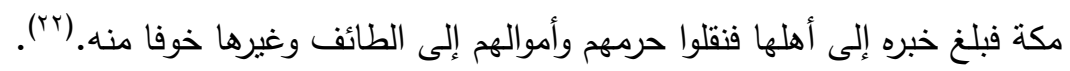

ووصل الأمر بالقرامطة أن قلعوا الحجر الأسود ونقلوه إلى مدينة هجر في البحرين، ذكر ابن الأثير في

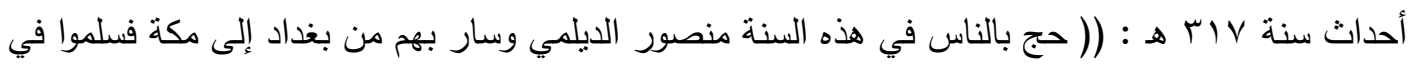

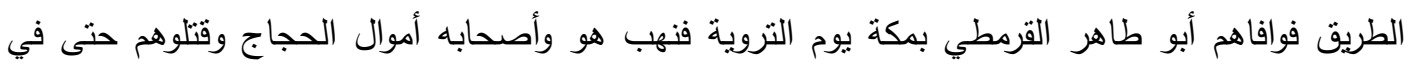

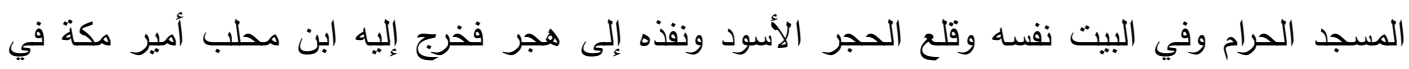

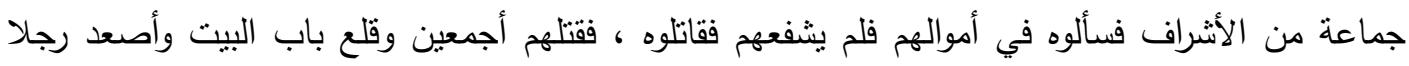

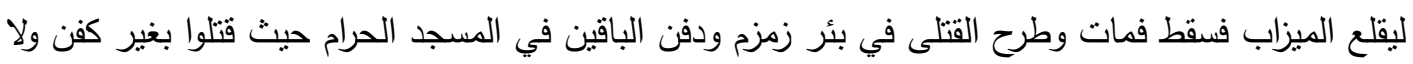

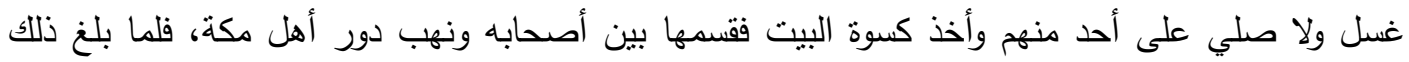
المهدي أبا محمد عبيد الله العلوي بأفريقية كتب إليه ينكر عليه ذلك ويلومه ويلعنه ويقيم عليه القيامة ويقول

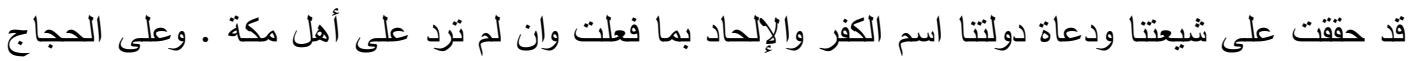

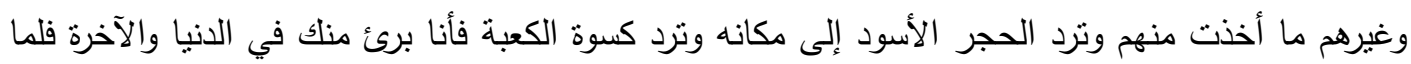

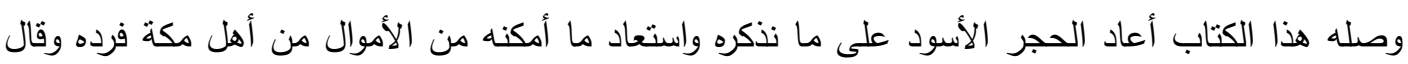

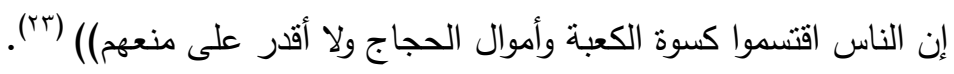

لذا فإن حجاج العراق في هذه السنة سلكوا طريق الموصل ثم الثام، لانقطاع الطريق بسبب

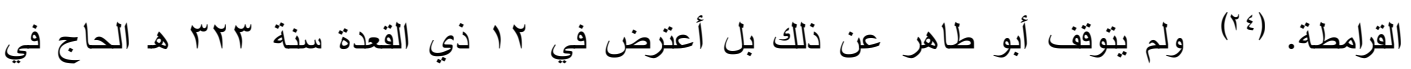

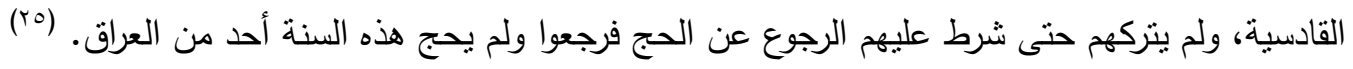


وبعد Y T سنة اعاد القرامطة الحجر الاسود في ذب القعدة من سنة وبr هـ الى مكة، وقالوا:

اخذناه بأمر وأعدناه بأمر، وكان بجكم بذل لهم خمسون الف دينار لقاء رده فرفضوا، ثم اعادوه بلا مقابل.

\section{المبحث الثانسي \\ العامل السباسي}

لعب العامل السياسي دورا كبيرا في العمل دون القيام بمناسك الحج كما ينبغي أو الحيلولة دون أداء الحج

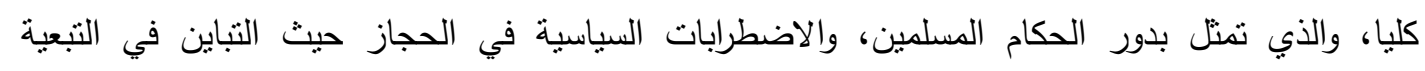

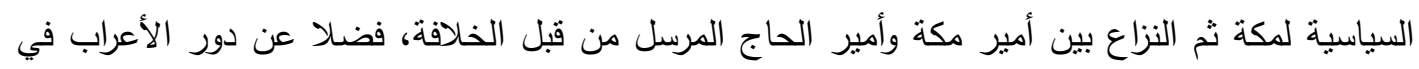

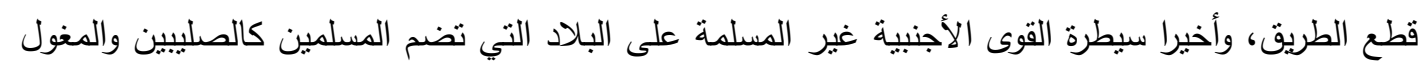
والأسبان.

\section{أولا: دور الحكام المسلمبن:}

تدخل بعض الحكام في أمور الحج، وحالوا دون اداء مناسك الحج لاعتبارات سياسية، كما فعل عبد

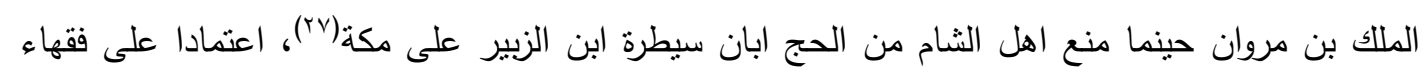

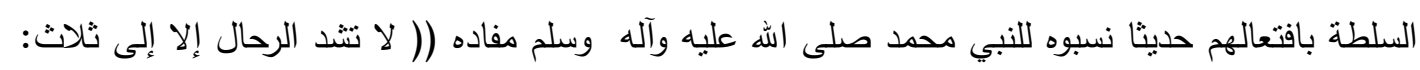

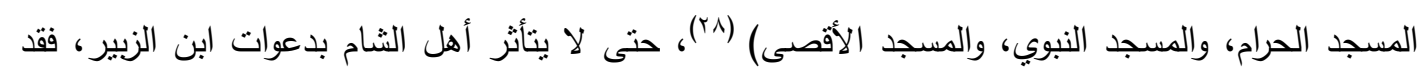

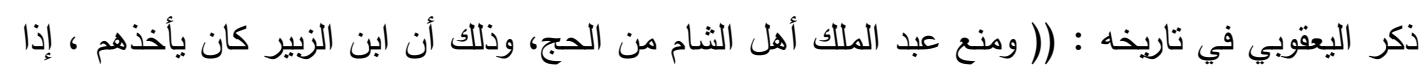

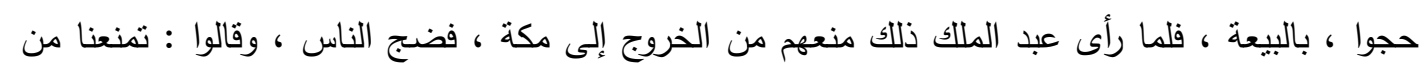

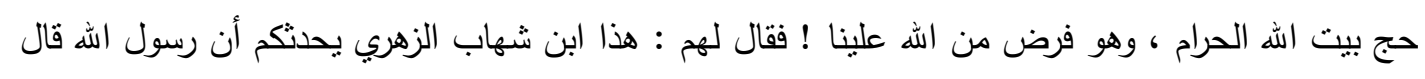

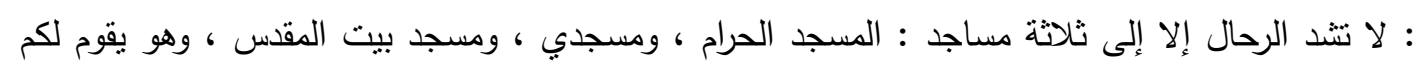

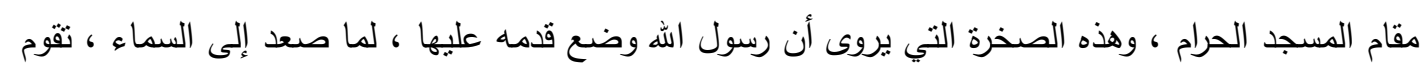

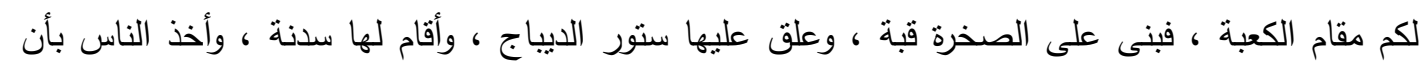

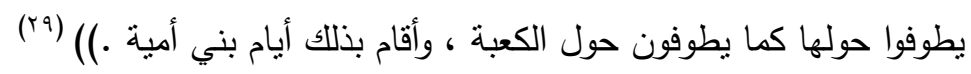


حالت الاضطرابات السياسية في اضطرابات أمور الحج والحجاج، أو في عرقلة أداء مناسك الحج، ويمكن توضيح ذلك ب:

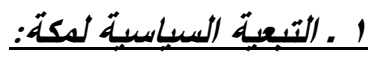

كانت التبعية السياسية لمكة أثر سلبي كبير في مناسك الحج، فكانت التبعية بين الخلافة العباسية والخلافة الفاطمية، ففي سنة وهاهـ كانت الخطبة في مكة لكل من الخليفة العباسي المطيع وللخليفة

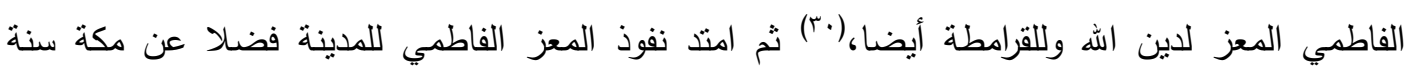

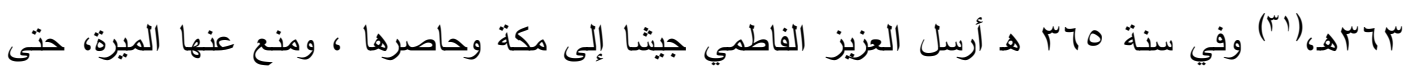

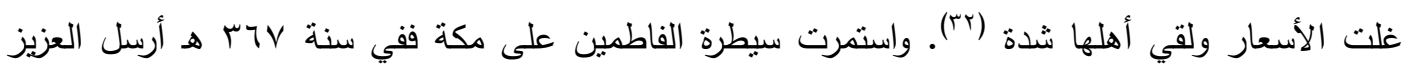

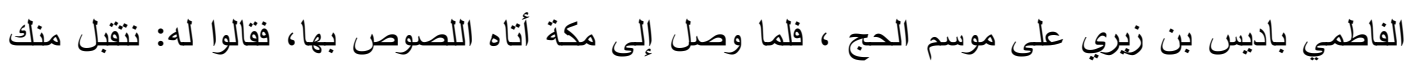

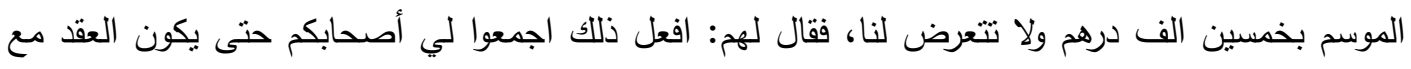

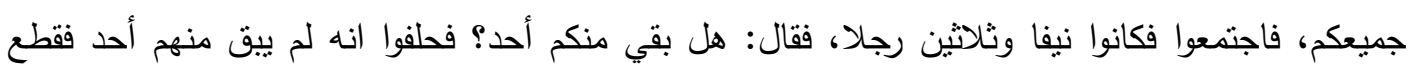
أيديهم كلّهم . (r)

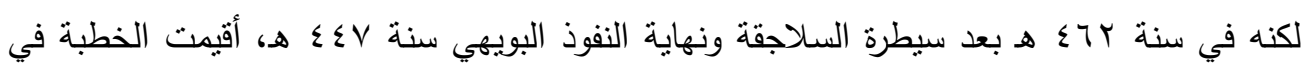

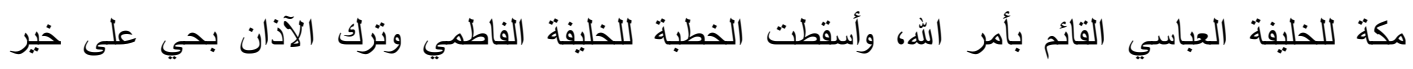

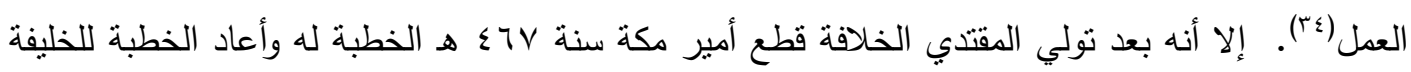

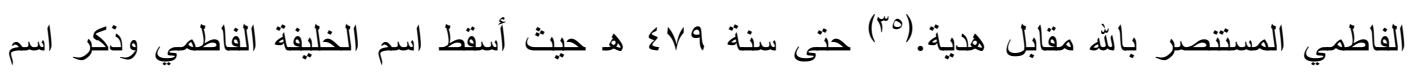

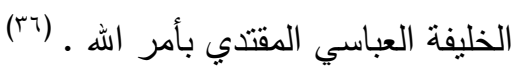

ثم ما لبث أن تحول الصراع بين أمراء السلاجقة، وضعفت الخلافة العباسية، فانقطعت كسوة

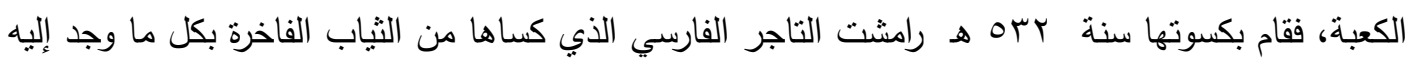

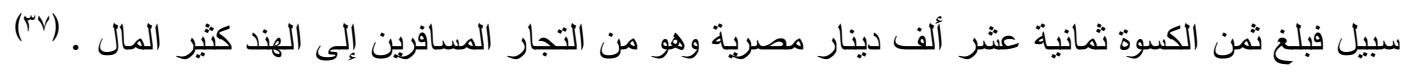


أثز ضعف الخلافة العباسية وسيطرة القوى الأجنبية عليها كالسلاجقة، وانشغال الأخيرين بالصراع فيما بينهم، غلب الأمراء على مكة وأخذوا يحكمونها كيفما يشاؤون، فأخذوا يفرضون الأموال على الحجاج، وتظورت الأمور إلى أن أمير مكة كان يدخل في نزاع ومعارك مع أمير الحج الذي نرسله الخلافة إذ يفرض

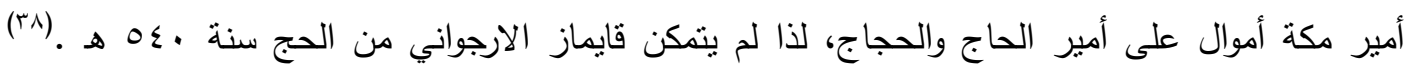
واستمرت حالة عدم الاستقرار في السنوات التالية، ففي سنة OOVه أفسد جماعة من عبيد مكة في الحاج بمنى، فتصدى لهم أصحاب أمير الحاج وقتلوا منهم جماعة، فجمع من بمكة وأغاروا على جمال الحاج وأخذوا ألف جمل، فاشتبك الطرفان، وقتل جماعة ونهب جماعة من الحاج وأهل مكة فرجع أمير الحاج ولم

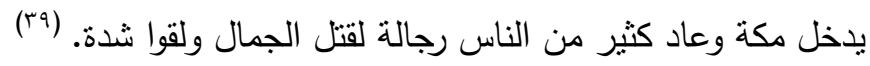

وقد تولى أمر مكة قتادة بن إدريس العلوي ثم الحسيني(·)، وكانت ولايته اتسعت من اليمن إلى المدينة المنورة، وكثر عسكره واستكثر من المماليك وخافه العرب في تلك البلاد خوفاً عظيماً . وكان أول ملكه لما ملك مكة حسن السيرة وأزال عنها العبيد المفسدين وحمى البلاد وأحسن إلى الحجاج وأكرمهم وبقي كذلك مدة ثم إنه بعد ذلك أساء السيرة وجدد المكوس بمكة وفعل أفعالا شنيعة ونهب الحاج في بعض السنين، مما جعل الناس تتحامل عليه، ففي سنة ر •آهـ قتل أحد الحجاج أحد أتباع الأمير قتادة، ظنا منه أنه الأمير قتادة، فهاجم قتادة بمن معه الحجاج، وكان أمير الحاج صبي لا يعرف كيف يفعل، فخاف وتحير وتمكن أمبر مكة من نهب الحاج فنهبوا منهم من كان في الأطراف وأقاموا على حالهم إلى الليل. فاضطرب الحاج وباتوا بأسوأ حال من شدة الخوف من القتل والنهب، فقال بعض الناس لأمبر الحاج لينتقل بالحجاج إلى منزلة حجاج الثام، فأمر بالرحيل فرفعوا أثقالهم على الجمال واشتغل الناس بذلك فطمع العدو فيهم، وتمكن من النهب، والتحق من سلم بحجاج الثام فاجتمعوا بهم ثم رحلوا إلى الزاهر ومنعوا من دخول مكة، ثم اذن لهم في ذلك فدخلوها وتمموا حجتهم وعادوا ـ ثم ارسل قتادة ولده وجماعة من أصحابه إلى بغداد فخلوها

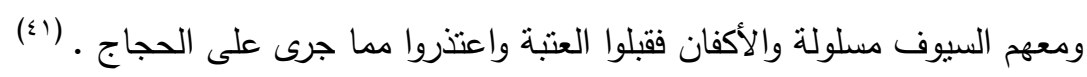

وفي سنة ^^آهـ توفي قتادة بن إدريس العلوي ثم الحسيني أمير مكة، كان له ولدان حسن وراجح، فتولى حسن الأمر، فيظهر أن راجح رفض ذلك وترك مكة وسكن خارجها وأخذ يخلق المشاكل لأخيه وينازعه، ولما سار حاج العراق بقيادة الأمير أقباش مملوك الخليفة الناصر لدين الله، وكان حسن السيرة مع 
الحاج في الطريق كثير الحماية فقصده راجح بن قتادة وبذل له وللخليفة مالا ليساعده على ملك مكة فأجابه

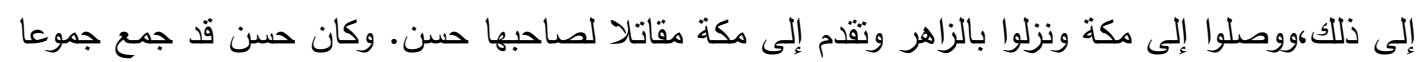

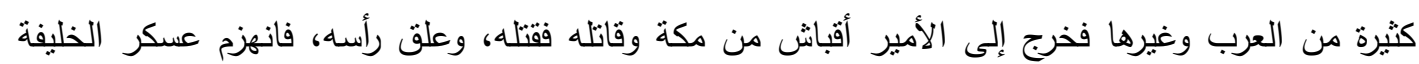

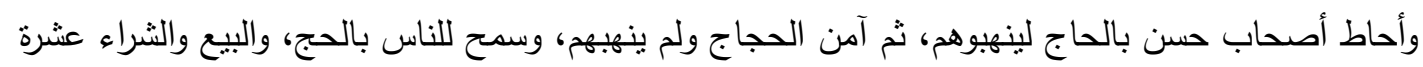
أيام، ثم عاد الحجاج إلى العراق. (זr)

وأحيانا يصل الأمر للصراع بين أمير مكة وأمير المدينة، كما في سنة ا. .7 هـ، ويظهر أن أمير مكة قتادة الحسني أراد أن يبسط سلطانه على المدينة أيضا، لكن قتادة أنهزم أمام والي المدينة سالم الحسيني

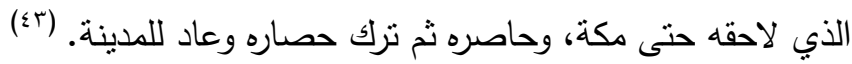

ثالثا: ــوف الأعلاب

بسبب ضعف بعض الأنظمة السياسية ينعدم الأمن في الطرق البرية المؤدية للحج، حيث قطاع

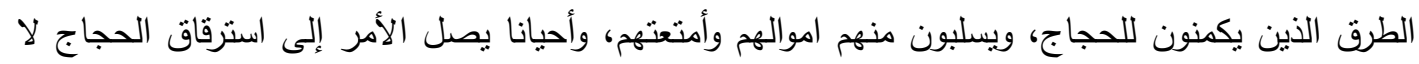

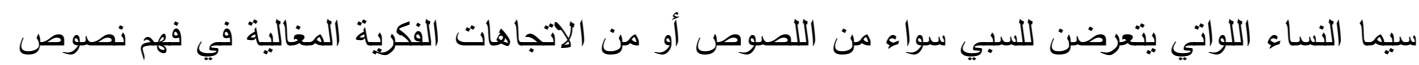
الثريعة الإسلامية، فضلا عن أعراب القبائل.

تحدثا الروايات التاريخية عما تقوم به بعض القبائل العربية من قرصنة على طريق الحجاج، كطيء

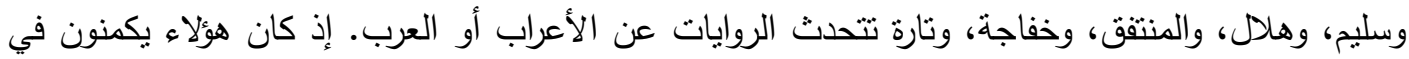

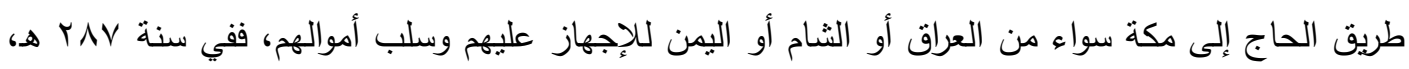

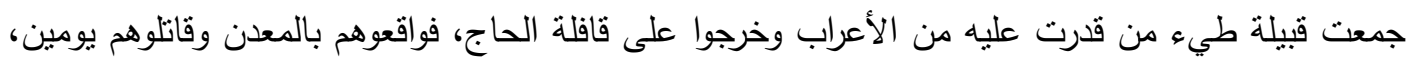

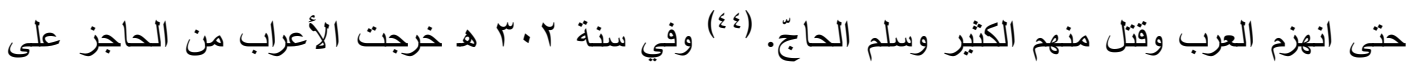

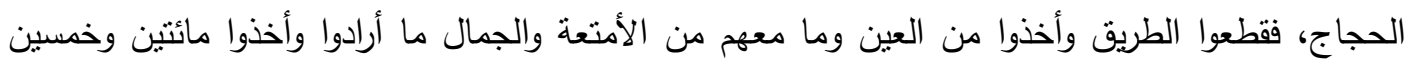

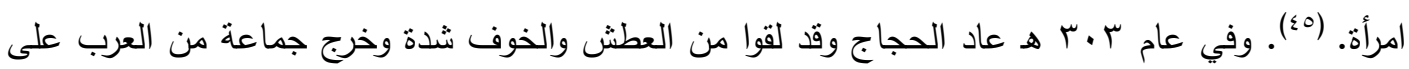

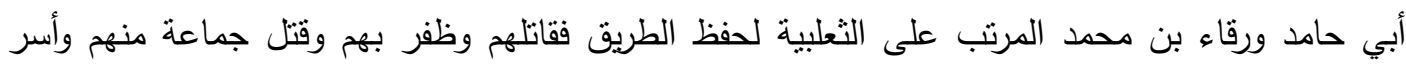

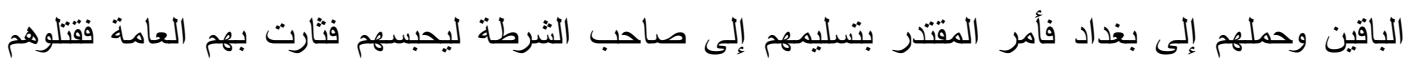

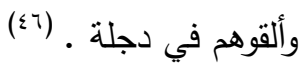




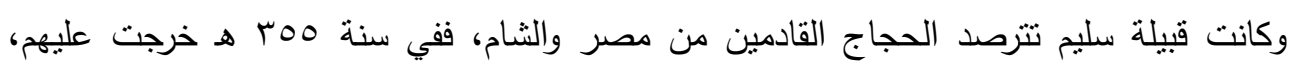

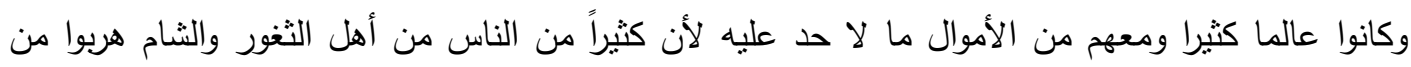

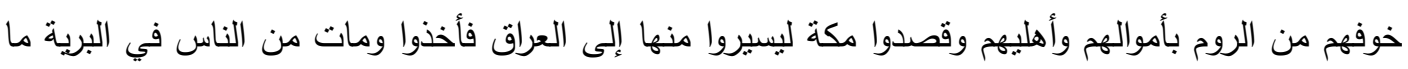

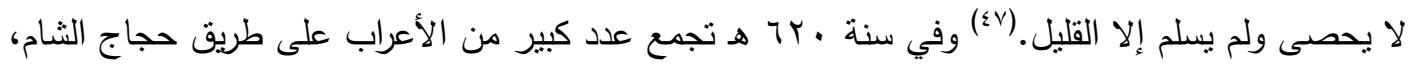

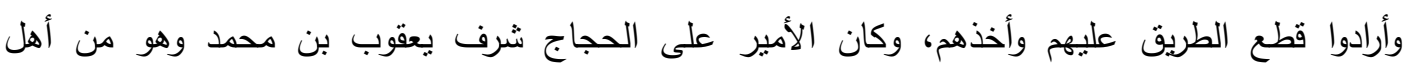

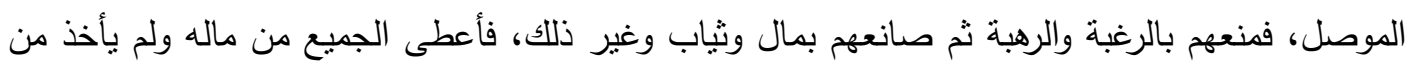

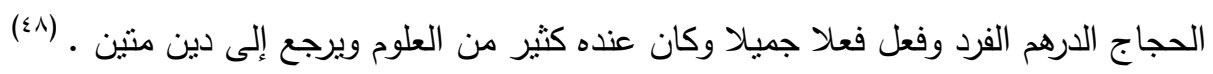

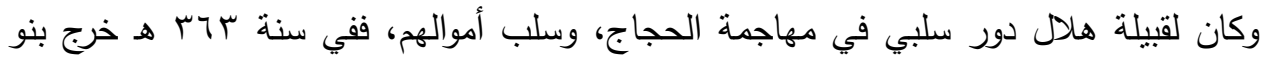

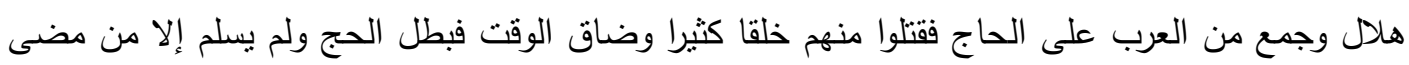

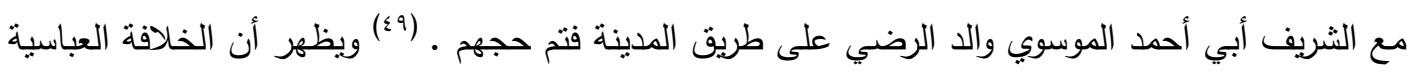

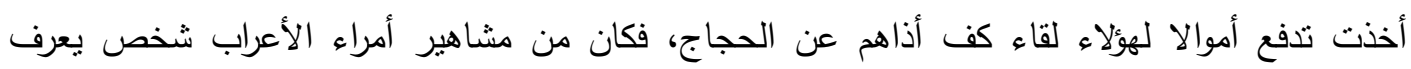

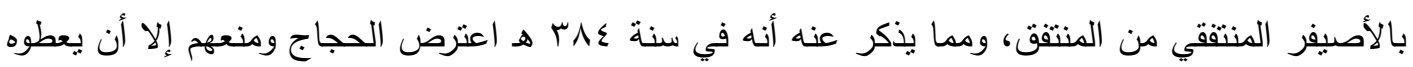

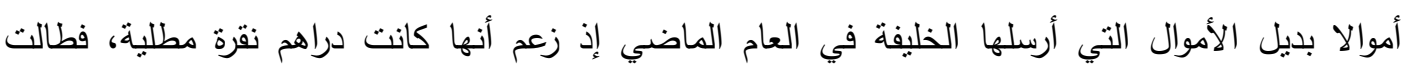

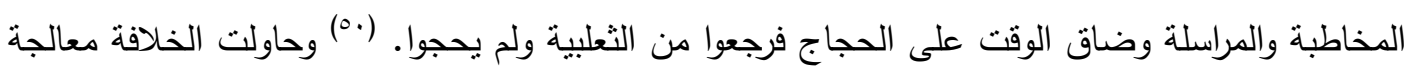

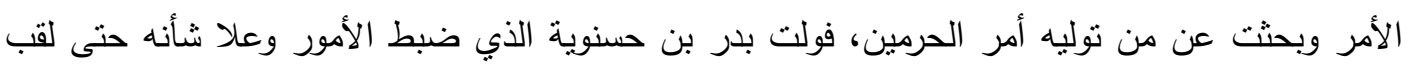

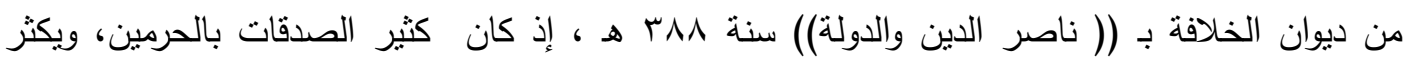

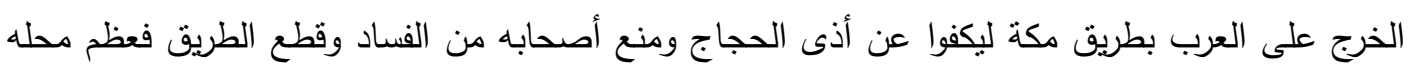

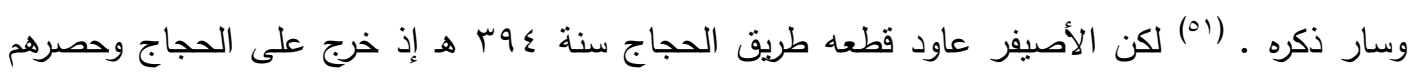

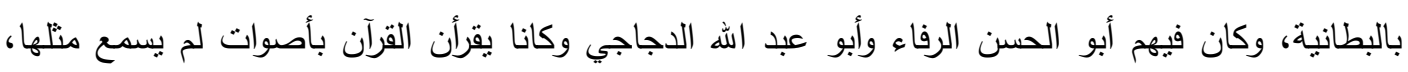

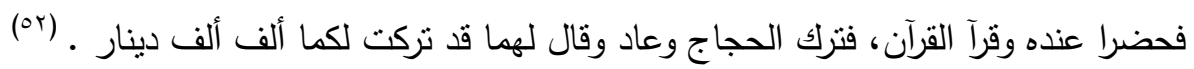

وكانت قبيلة خفاجة تستخدم طرقا دنيئة مع الحجاج ففي سنة r •؛ هـ سارت خفاجة إلى واقصة

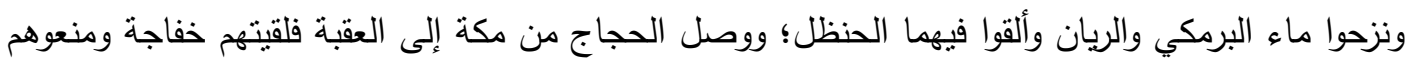

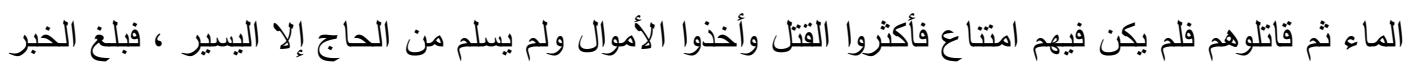
فخر الملك الوزير ببغداد ، فسير العساكر في أثرهم وكتب إلى ابن مزيد بطلب العرب، فسار خلفهم فلحقهم 
وقد قاربوا البصرة فأوقع بهم فقتل منهم وأسر جمعا كثيرا، وأخذ من أموال الحاج ما رآه وكان الباقي قد أخذه

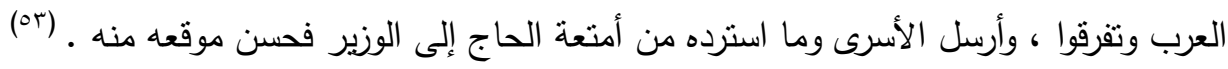

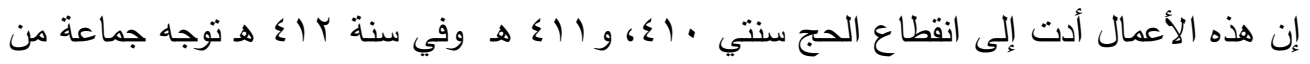

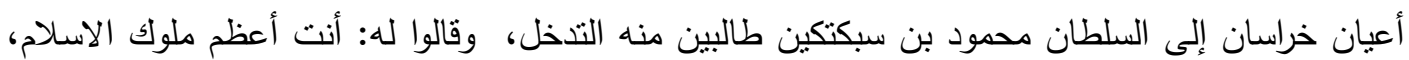

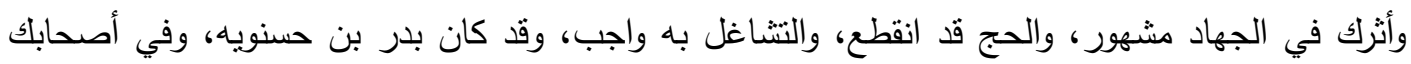

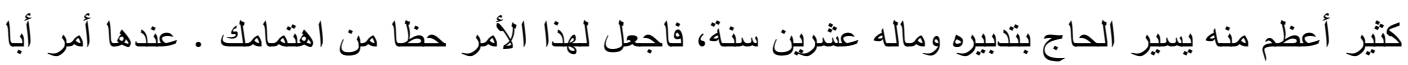

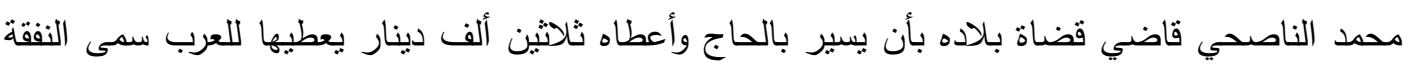

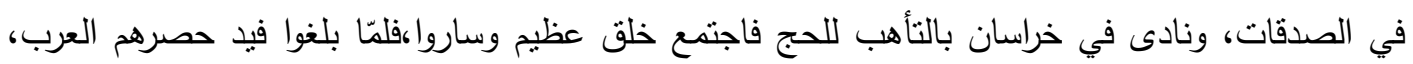

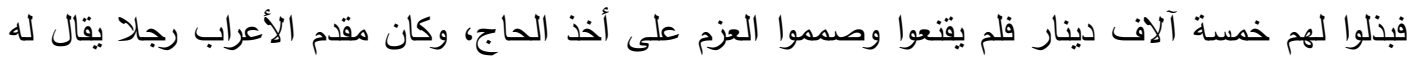
حمار بن عدي بضم العين من بني نبهان، فركب فرسه وعليه درعه وسلاحه وجال جولة برهب بها ، وكان

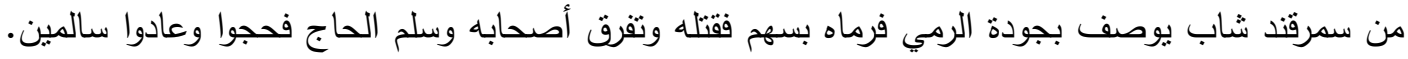

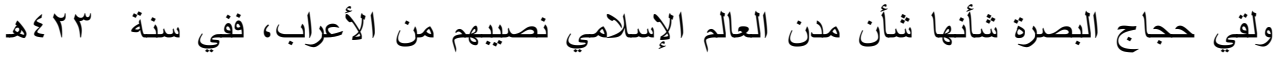

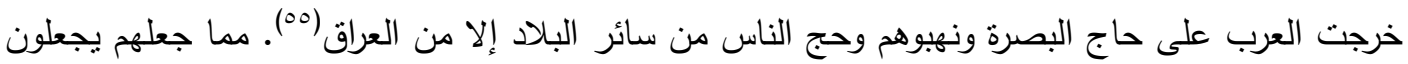

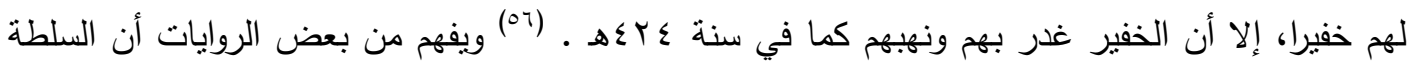

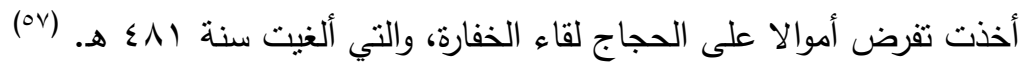

وقد أستغل الأعراب أحيانا الثائعات حول موت الخليفة فيهاجمون المدن والحجاج، كما فعلت

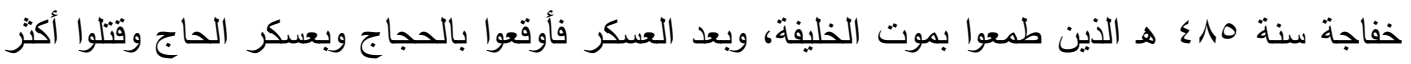

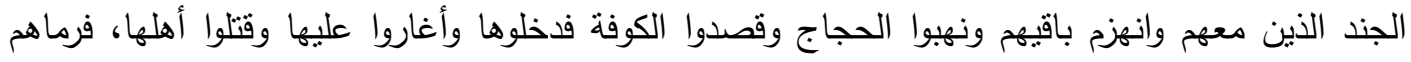

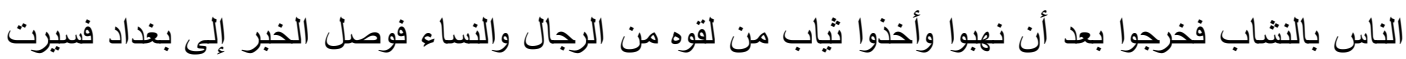

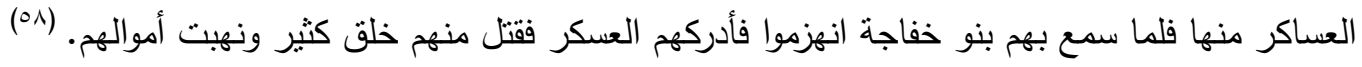

لهذه الأسباب توقف الحج من العراق، مما دفع البعض للحج عن طريق دمثق، ففي سنة 1 كي؛ هـ

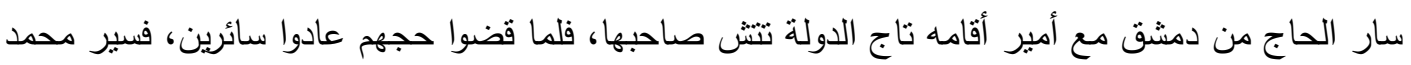


بن أبي هاشم وهو أمير مكة جيشا لدق الحجاج ونهب كثيرا من أموالهم وجمالهم فعادوا إليها ولقوه وسألوه أن

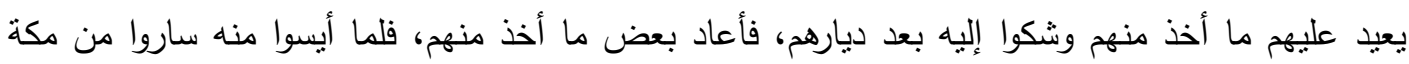

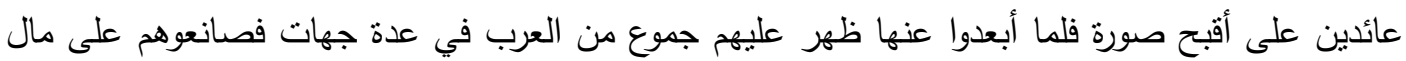

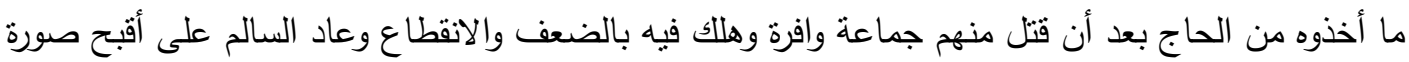

وكان الحجاج بعد تأدية مناسك الحج في مكة ينوجهون إلى المدينة المنورة لتجديد العهد بالنبي

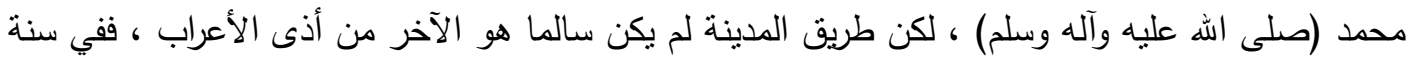

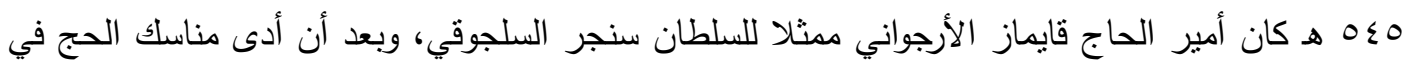

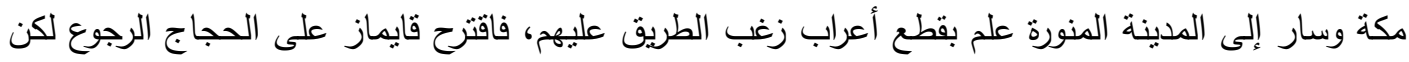

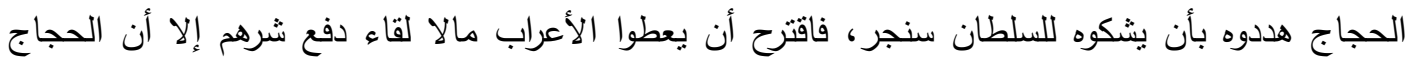

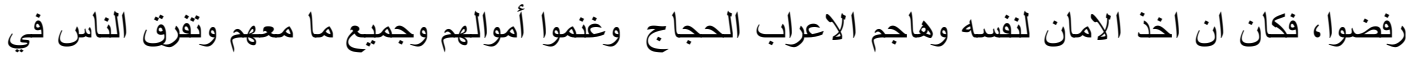

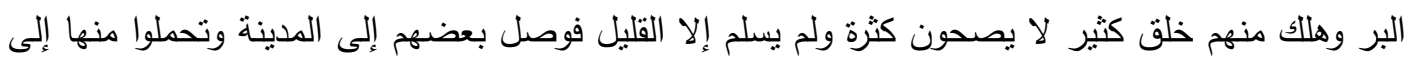

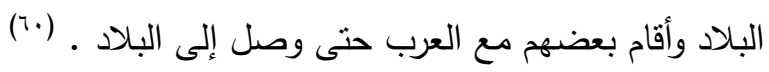

وفي سنةهاه هـ حج الناس فلما وصلوا إلى مدينة النبيّ ، صلّى الله عليه وسلّم ، وصل لهم الخبر أن العرب قد اجتمعت لتأخذهم فنركوا الطريق وسلكوا طريق خيير فوجدوا مشقة شديدة ونجوا من إنى

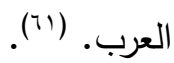

ولم يقتصر قطع الطريق على الأعراب بل في مناطق شرق العالم الإسلامي أحيانا يقوم الجند

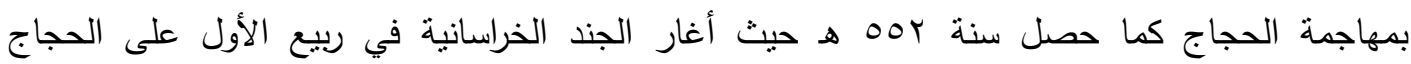

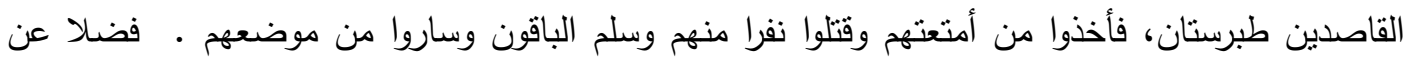

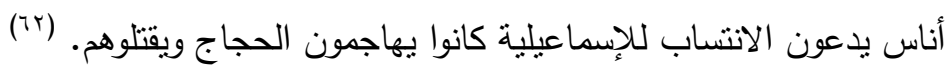

وفي سنة 070 هـ كثرت الأذية من عبد الملك بن عطاء، وتطرق إلى بلاد حلوان، ونهب وأفسد

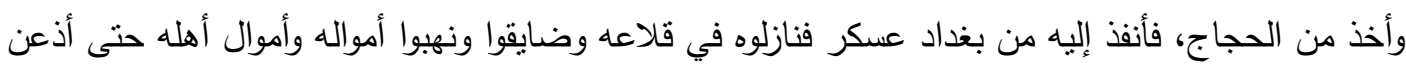

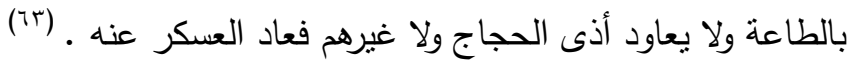


إن ما يصدر من الأعراب بحق الحجاج من مطالبات مالية ترهق الحجاج جعل أمراء الحجاج

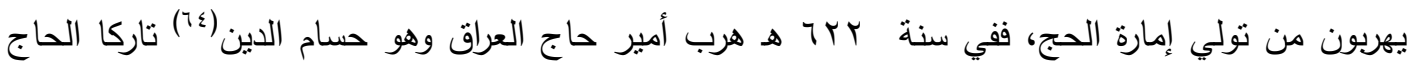

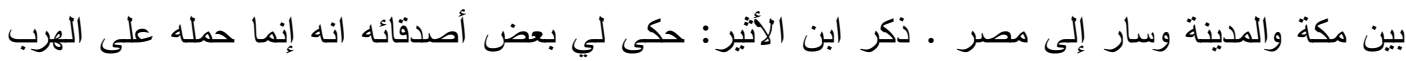

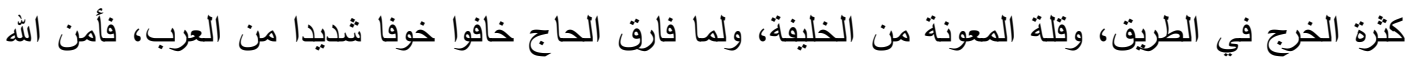

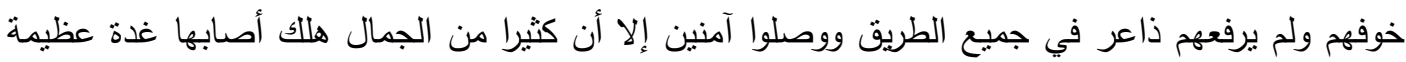

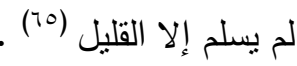

ويفهم من النصوص أن أهل مكة مارسوا اللصوصية مع الحجاج، ففي سنة Vדبهـ عين العزيز

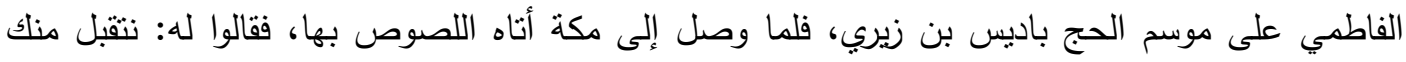

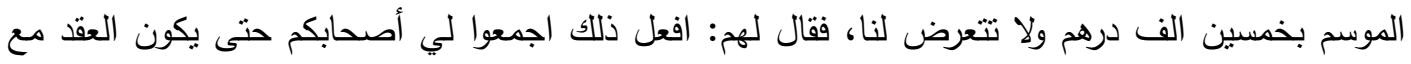
جميعكم، فاجتمعوا فكانوا نيفا وثلاثين رجلا، فقال: هل بقي منكم أحد؟ فحلفوا انه لم يبق منهم أحد، فقطع لئع

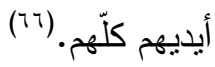

\section{لابعا: . سبطرة القوى الأجنيية:}

بسبب وقوع بعض المدن الإسلامية تحت سيطرة القوى الأجنيية غير الإسلامية، أدى إلى تحكم

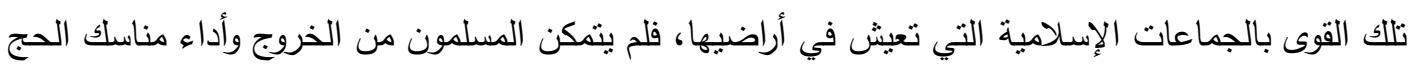

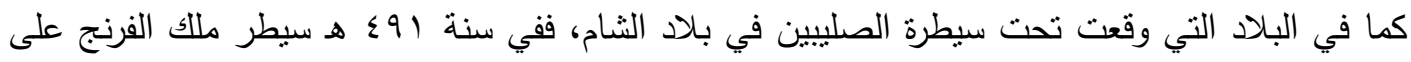

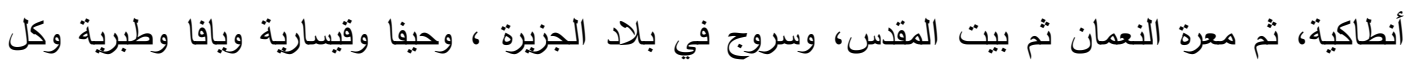

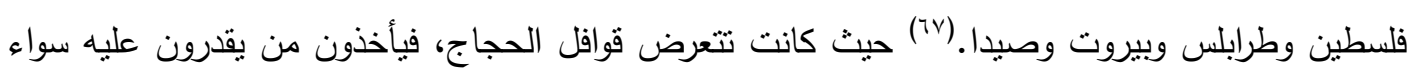

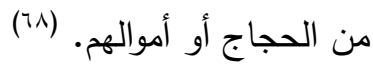

وكانت أثد القوى الأجنبية هم المغول(79) الذين كان لهم أثر سلبي كبير في تغيير خارطة العالم

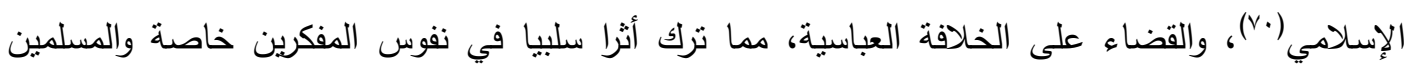

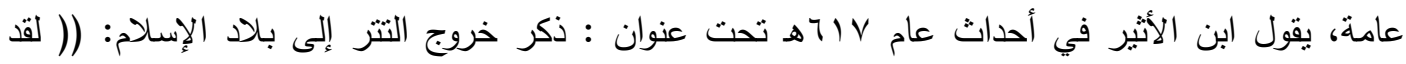

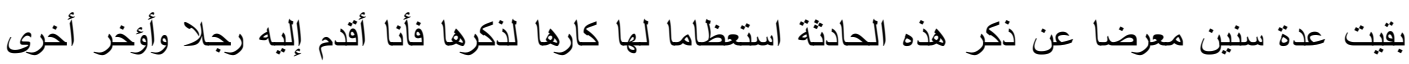
فمن الذي يسهل عليه أن يكتب نعي الإسلام والمسلمين ومن الذي يهون عليه ذكر ذللك فياليت أمي لم تلدني 
ويا ليتي مت قبل هذا وكنت نسيا منسيا إلا أني حثي جماعة من الأصدقاء على تسطيرها وأنا متوقف ثم الترن رأيت أن نرك ذلك لا يجدي نفعا فنقول هذا الفعل يتضمن ذكر الحادثة العظمى والمصيبة الكبرى التي عقت الته

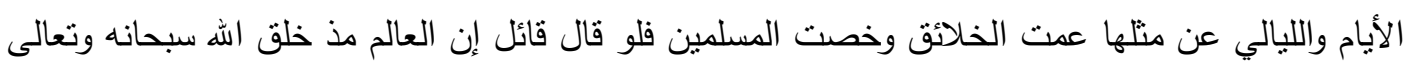

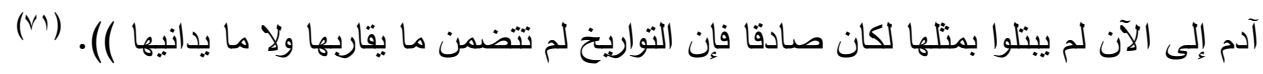

ويضيف قائلا: (( هؤلاء لم يبقوا على أحد بل قتلوا النساء والرجال والأطفال وشقوا بطون الحوامل وقتلوا

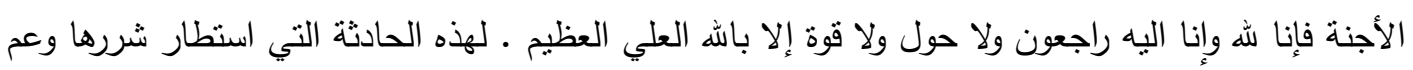

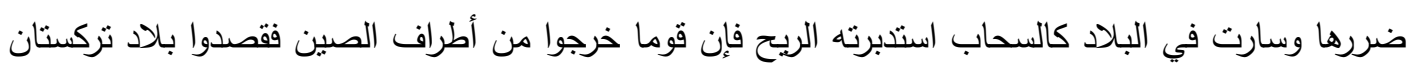

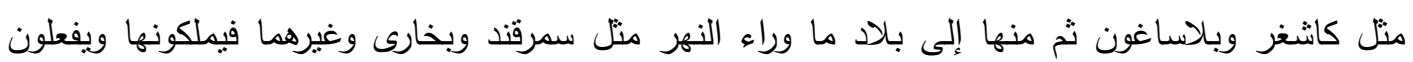

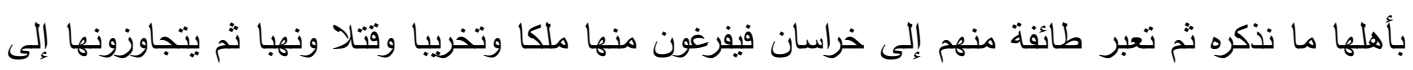

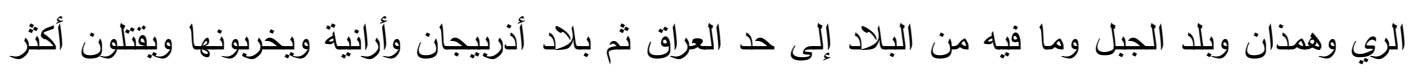

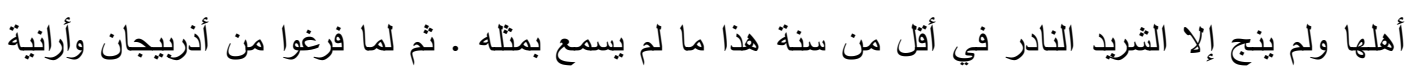
ساروا إلى دربند شروان فملكوا مدنه ولم يسلم غير القلعة التي بها ملكهم ، وعبروا عندها إلى بلد اللان واللكز

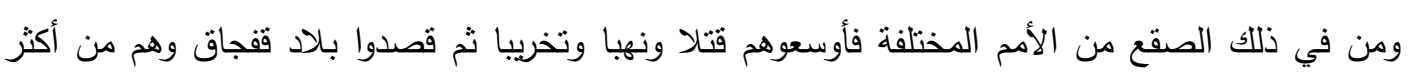

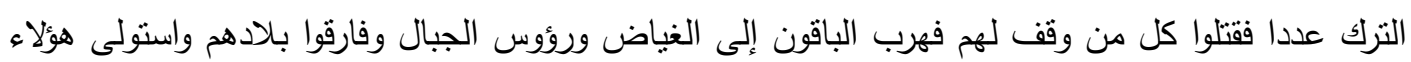

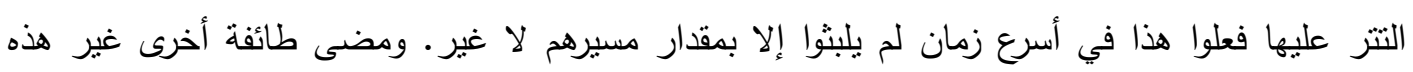

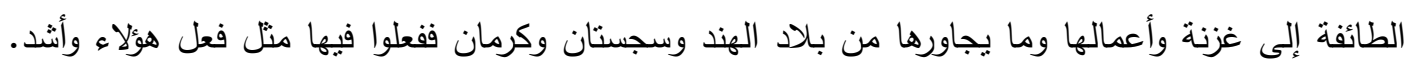

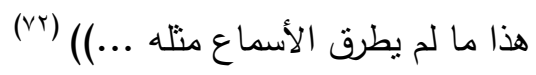

ان ذلك الحدث التاريخي الكبير ترك اثره السلبي على جميع الاصعدة في العالم الاسلامي، حيث حل

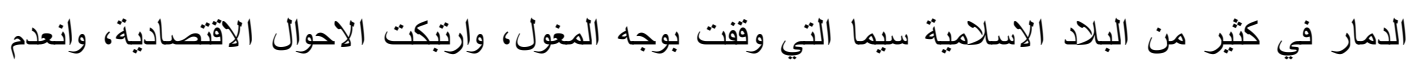

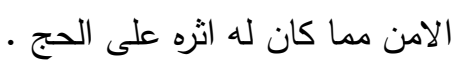

وكذا الحال في سيطرة الاسبان في الأندلس، فبعد سقوط الدولة الأموية في الأندل، امند نفوذ

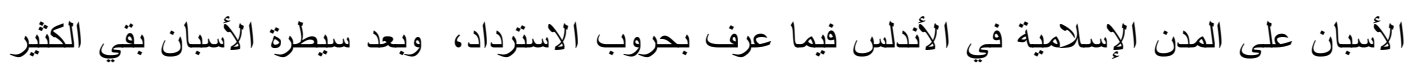

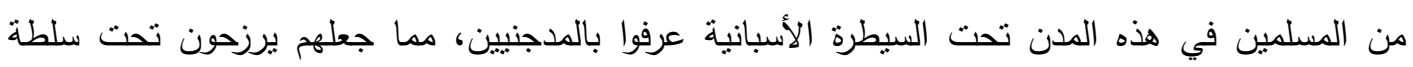


تباينت في تعاملها معهم لينا وشدة، فكانت أحيانا قليلة تسمح لهم بممارسة شعائرهم ، وأحيانا تشتد عليهم

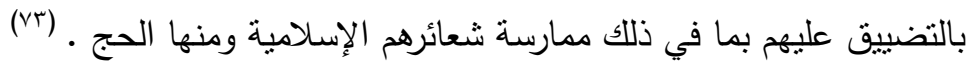

لقد كان سقوط الاندلس الاسلامية بيد الاسلام من فواجع الإسلام فالمسلمين لم يخسروا ارض فقط

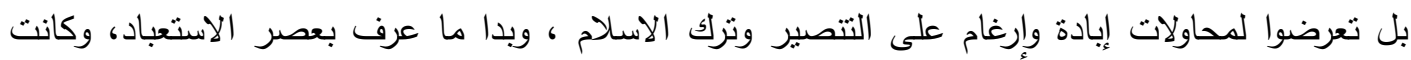
الكنيسة تؤكد على ضرورة سحق طائفة محد من إسبانيا فنشط ديوان التحقيق بدعم الكنيسة قضاءه المدمر ، فنتصر الكثير من المسلمين رهبة، وتحولت المساجد الى كنائس، وأحرقت كل المؤلفات العربية، واتخذت الته اجراءات متثددة على من لم يعلن تتصره، ولا يحق لله الاتصال بمن في المغرب وسائر بلاد الإسلام، ومن

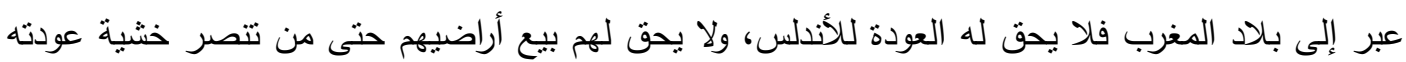

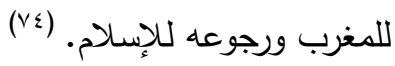

لقد ورد في وثيقة تتئير لدور الملوك العلويون في المغرب إلى ما يتعرض له المسلمون تحت

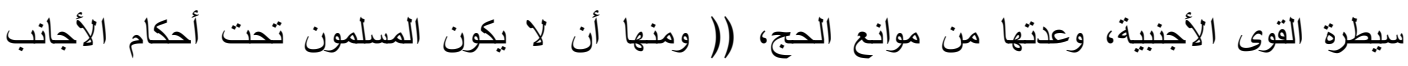

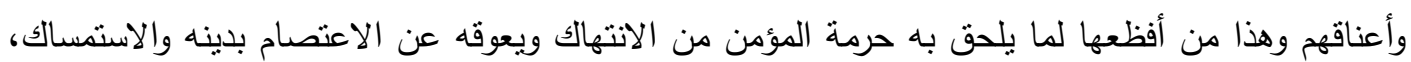
ولما صار الحجاج يقتحمون هذه الطاعة من غير إمكان واستطاعة أوقعوا أنفسهم في الدحظور ، واستوجبوا لاعنها الكف عن السفر لأمور منها ... كونهم تلك المدة تحت أحكام الأجانب الذين بعوقونهم عن الديانة والقيام بالواجب، ومنها ما يقع للنساء المسلمات من إكراه أهل المراكب لهن على الفحشاء زيادة على الأبلى اختلاطهن

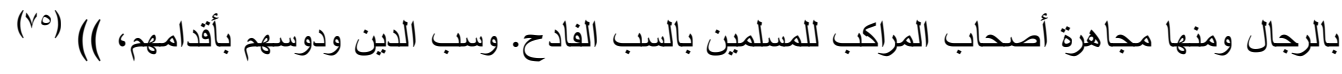




\section{المبحث الثالث}

\section{الكوارث الطبيعبة:}

كثر ما تتعرض بلاد الحجاز أو غيرها من بلدان العالم الإسلامي لكوارث طبيعية تحول دون القيام

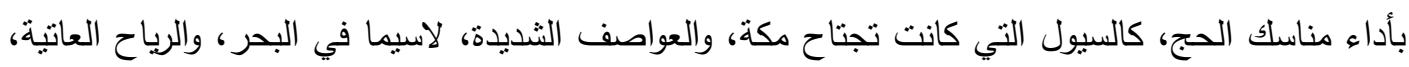

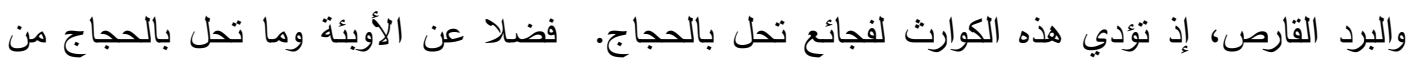

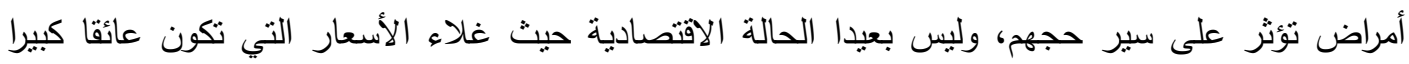

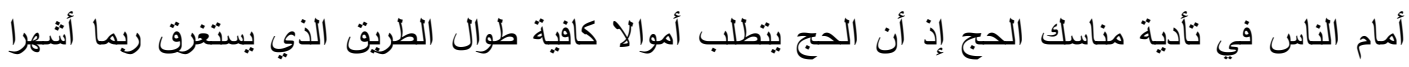
سيما البلاد البعيدة عن الحجاز كالأندلس وأقصى المشرق مناسئ وأفريقيا.

كانت السيول من معوقات الحج التي تركت آثارا سلبية وحالت دون أداؤه أو الآثار السلبية المترتبة على مكة والحجاج، فقد تعرضت مكة إلى تسعين سيلا(17) منها:

سيل فارة: ذكر الأزرقي أن وادي مكة سال في الجاهلية سيلا عظيما، وكانت مقاليد الكعبة بيد خزاعة، وأن

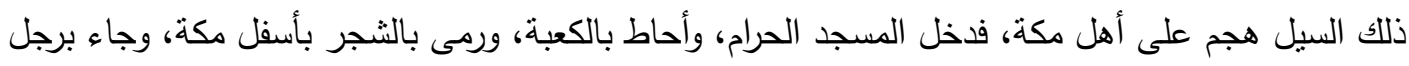

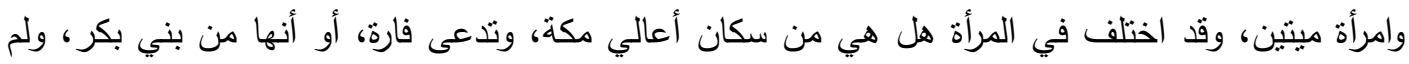

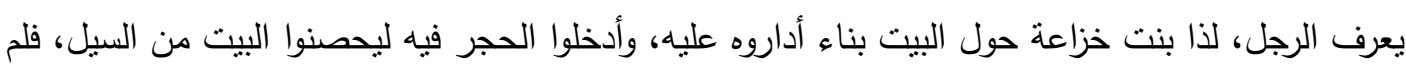

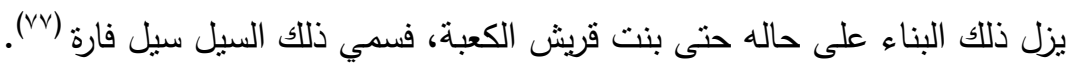

سيل أم نهيل: من سيول مكة في أيام عمر بن الخطاب، أقبل من أعلى مكة حتى دخل المسجد الحرام،

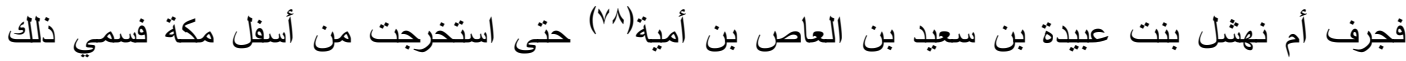

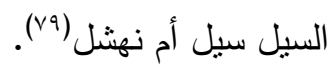

وقد جرف هذا السيل مقام النبي إبراهيم (عليه السلام) من موضعاه، فذهب به حتى وجد بأسفل مكة، فأنى

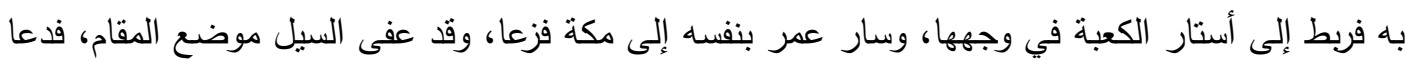

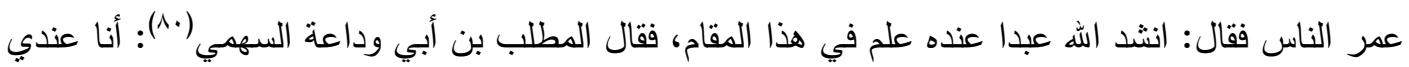
ذللك، فقد كنت أخثى عليه هذا فأخذت قدره من موضعه إلى الركن ومن موضعه إلى باب الحجر ومن لهن $r \cdot \Lambda$ 
موضعه إلى زمزم بمقاط|(') وهو عندي في البيت، فقال له عمر : فاجلس عندي، وأرسل إليها فأتى بها فمدها

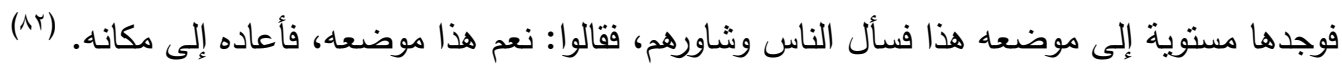

سيل الجحاف: وقع فجر يوم التروية سنة .1 هـ، (( ولم يكن المطر عام الجحاف على مكة إلا شيئا يسيرا

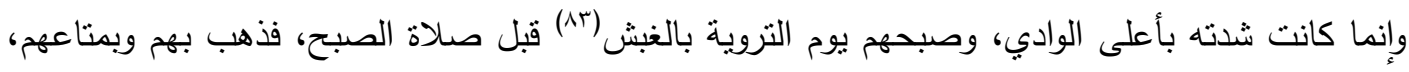

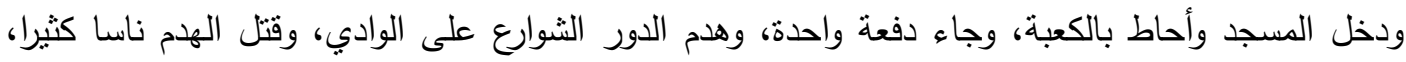

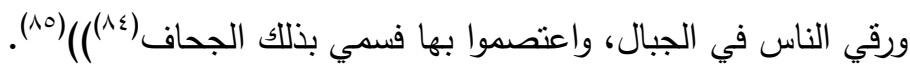

وقال فيه عبد الله بن أبي عمارة:

لم تر عيني مثل يوم الاثثين * أكثر محزونا وأبكى للعين

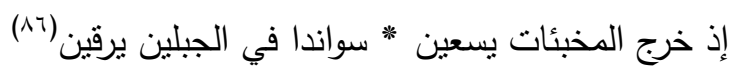

فكتب عبد الملك بن مروان إلى عامله على مكة بعد أن أرسل له مبلغا من المال يأمره بعمل ضفاير

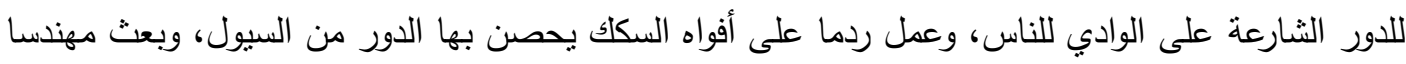

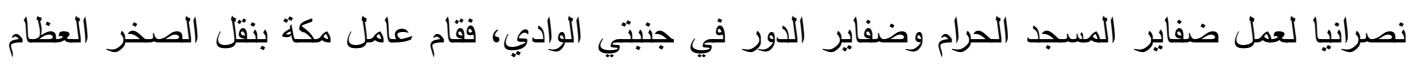

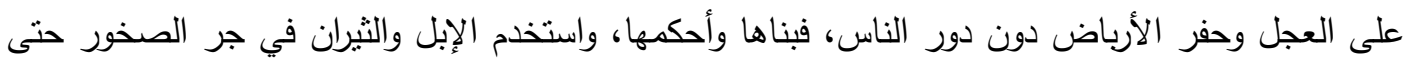

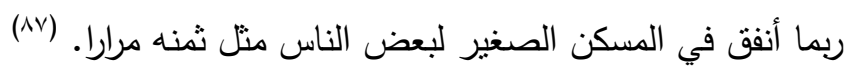

سيل المخلي: وقع سنة ؟ هـ، وكان عظيما دخل المسجد الحرام وأحاط بالكعبة، مرض الناس بسببه، وأصابهم شبه الخبل فسمي بسيل المخبل.

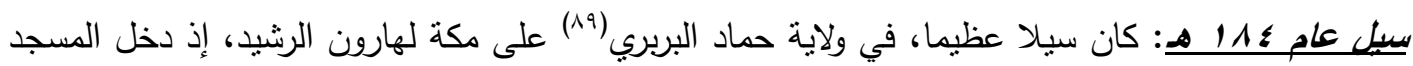

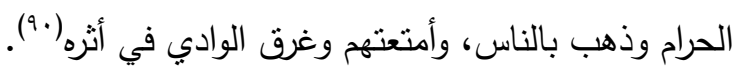

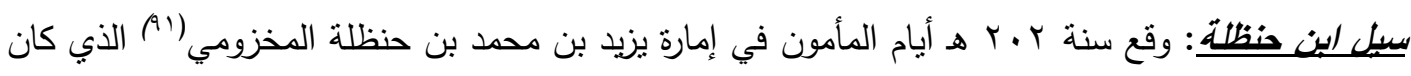

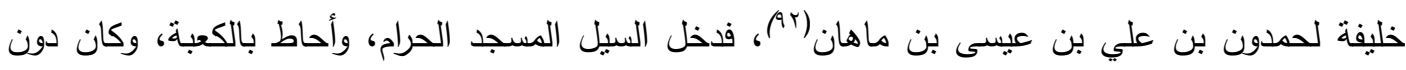
الحجر الأسود بذراع، فاضطروا إلى رفع المقام عن مكانه خوفا عليه أن يذهب به به السيل، وهدم السيل دورا 
من دور الناس، وجرف ناس كثير، وأصاب الناس بعده مرض شديد من وباء وموت فاش فسمي ذلك السيل

سيل ابن حنظلة(9r).

سيل سنة 1. 1 هـ: بعد من أخطر السيول التي تعرضت لها مكة، إبان إمارة عبد الهُ(9) بن الحسن بن

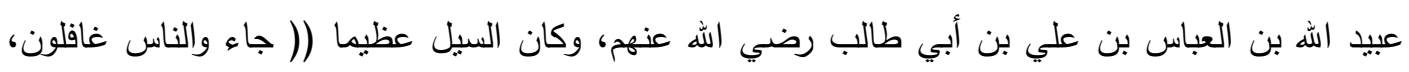

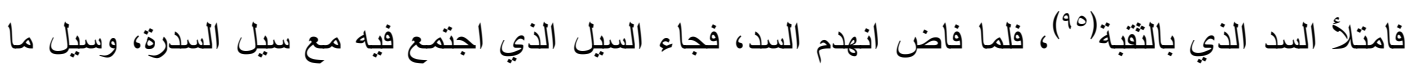

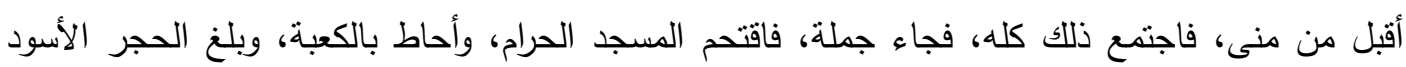

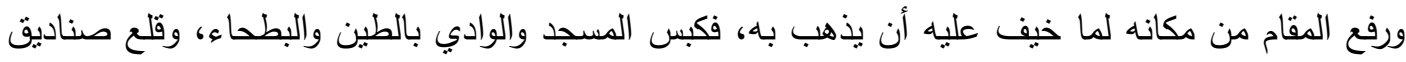

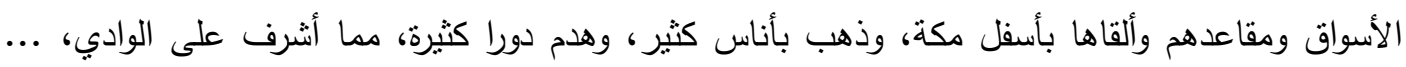

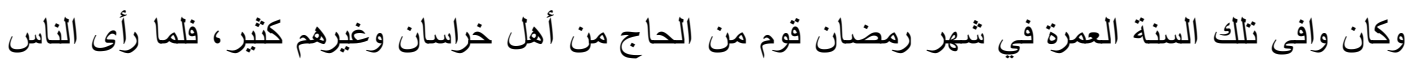

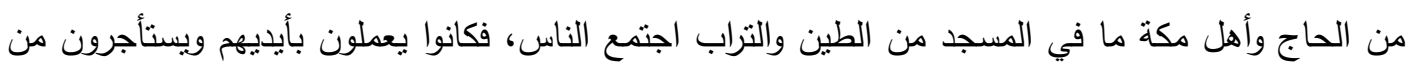

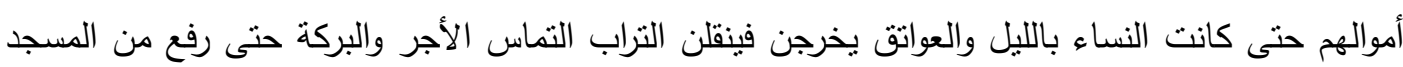

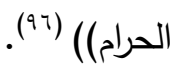

ثم أرسل المأمون مبلغا من المال، وأمر أن يعمل به في المسجد ويبطح ويعزق وادي مكة، فعزق منه

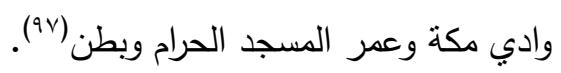

سيل سنة و ؛بهـ : بعد ان خرج الحجيج من مكة، ونزلوا واديا جاءهم سيل فأخذهم عن آخرهم والقى بهم

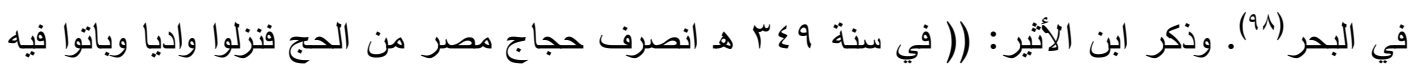

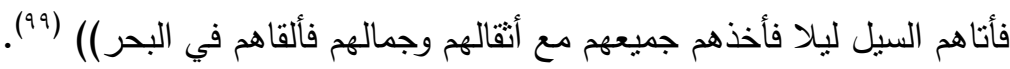

سيل سنة ودئ هـ : نرك آثنارا سيئة إذ جرف الكثير من الأموال والأنفس، ولم ينج منهم الا من تعلق

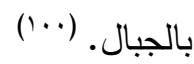

ولم يقتصر الأمر على مكة والحجاز بل شمل بلاد أخر ، فالعراق تعرض للعديد من السيول والفيضانات

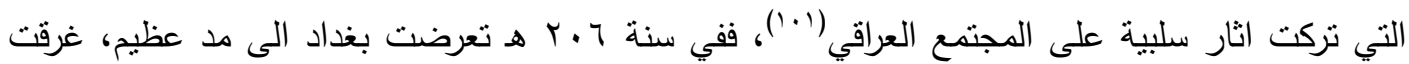

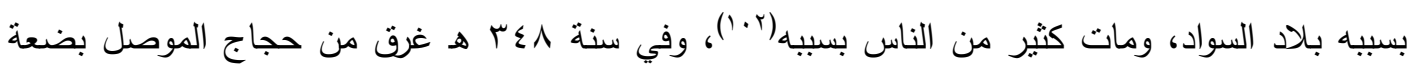




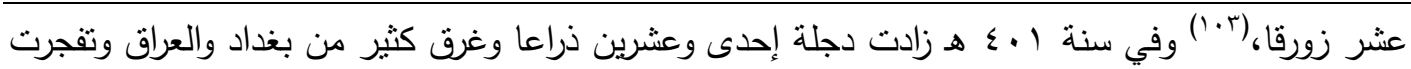

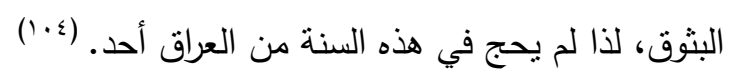

وكان عام 77 كاد هـ شديدا على أهل بغداد إذ زاد نهر دجلة، فغرق الجانب الثرقي وبعض الغربي منها.

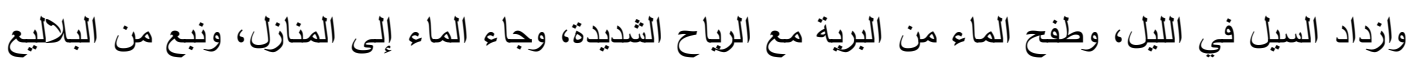

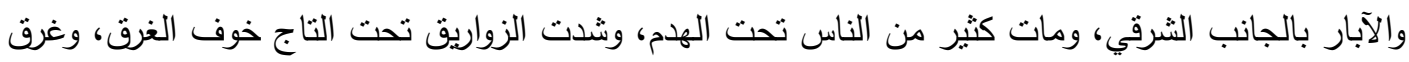

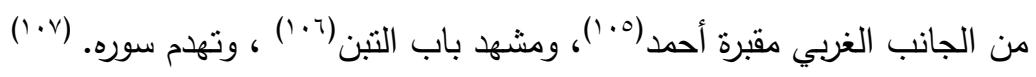

وفي سنة 119 هـ نزل الحجاج بوادي المياقت بعد نخله فأتاهم سيل عظيم فأغرق أكثرهم ونجا من نعلق

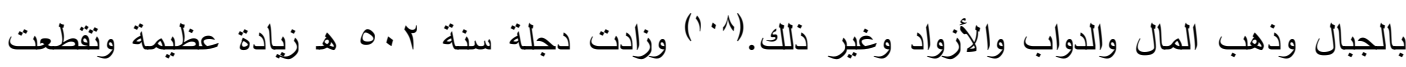

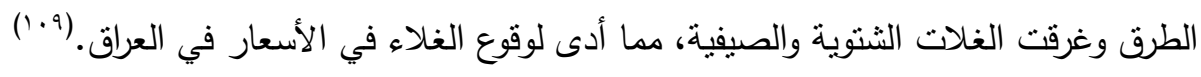
وتركت الرياح العانية الثديدة آثنارا مدمرة على المجتمع، إذ تؤدي إلى هدم البيوت وموت كثير من الناس،

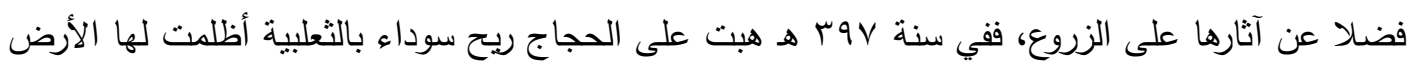

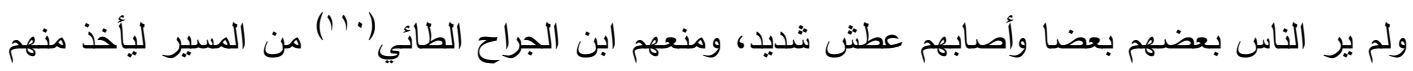
مالا، فضاق الوقت عليهم فعادوا ولم يحجوا. ('11)

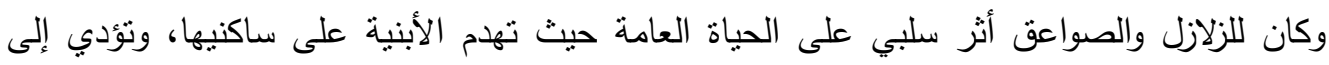

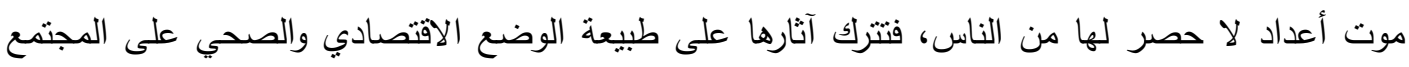

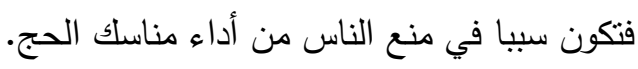

فببسبب الزلازل سنة 10 هـ تضعضع الركن اليماني من البيت الحرام، وإنهام بعضه وتشعث بعض حرم

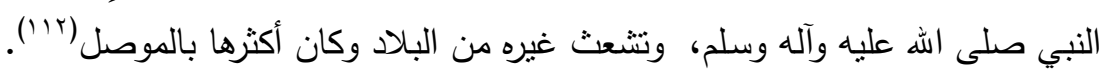

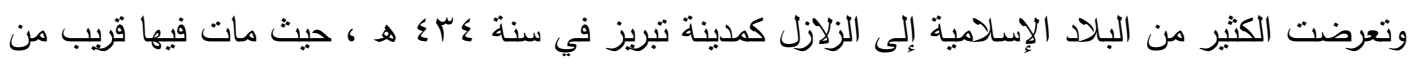

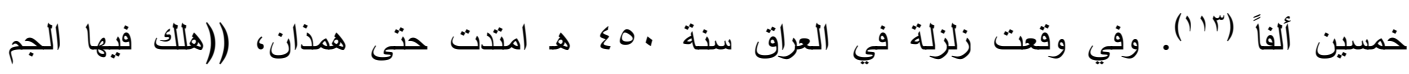

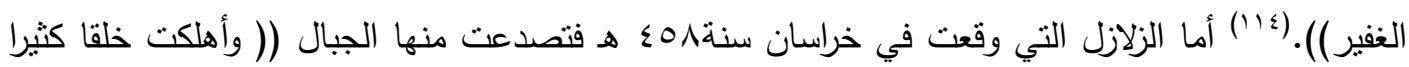

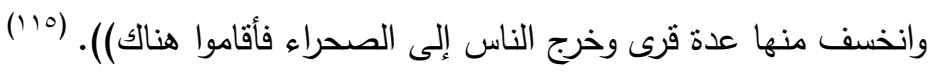




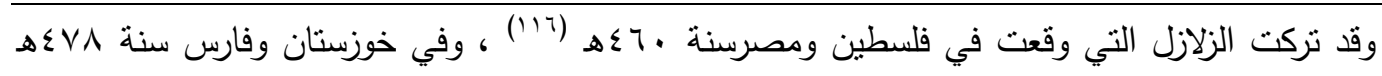

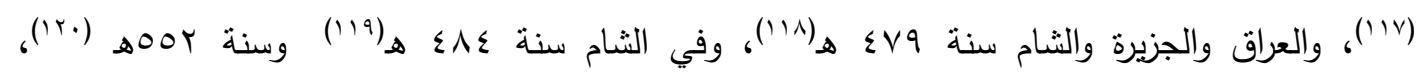

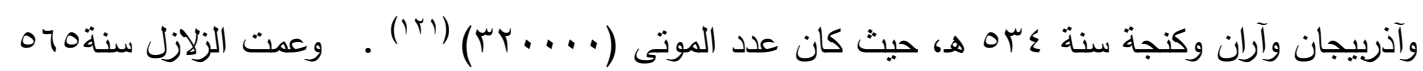

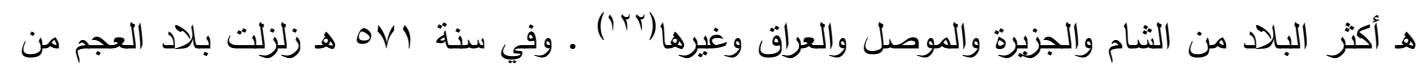

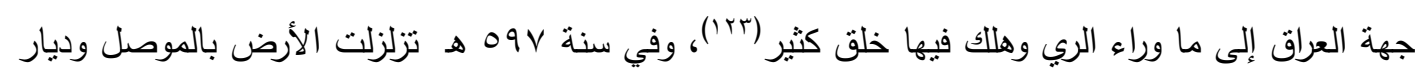

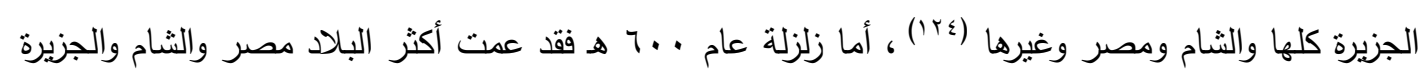

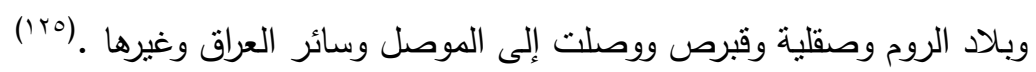

وعانت الدولة الإسلامية من الأوبئة التي كانت لها آثار سلبية على المتصع على جميع الأصعدة لا سيما

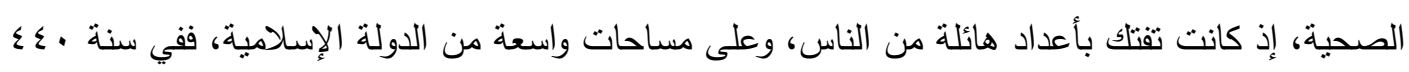

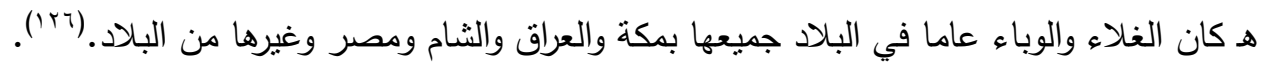

ولما حج الناس سنة 009 هـ لقوا شدة وانقطع منهم خلق كثير في فيد والثعلبية وواقصة وغيرها، وهلك

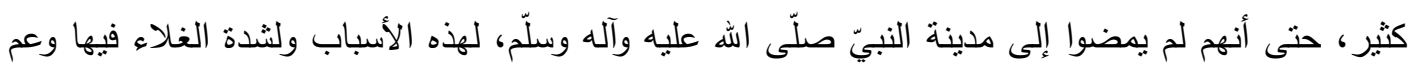
ما يقتات ووقع الوباء في البادية وهلك منهم عالم لا يحصون وهلكت مواثيهم وكانت الأسعار بمكة غالية.

ولم يقتصر أثر الأوبئة على مكة، بل وقعت الأوبئة في شتى بقاع العالم الإسلامي، وتركت آثارا سيئة،

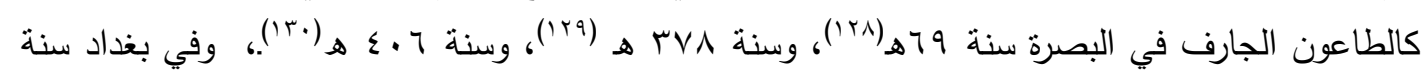

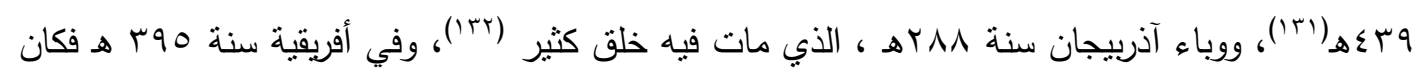

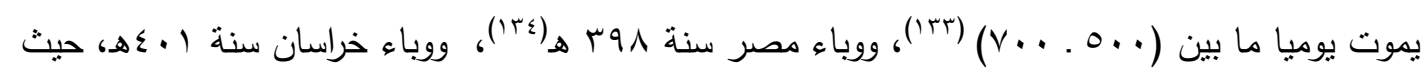
كان الإنسان يصيح الخبز الخبز! ويموت، ثم تبعه وباء عظيم حتى عجز الناس عن دفن الموتى. (1) (1).

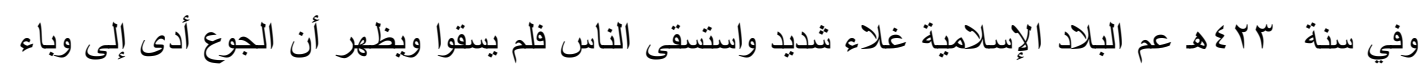

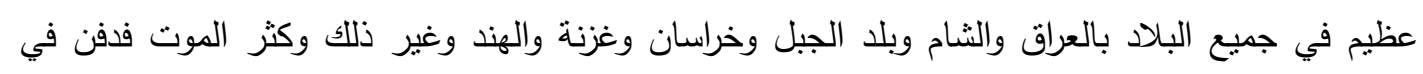

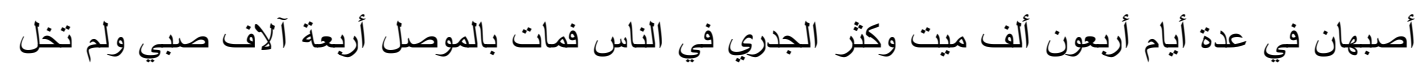

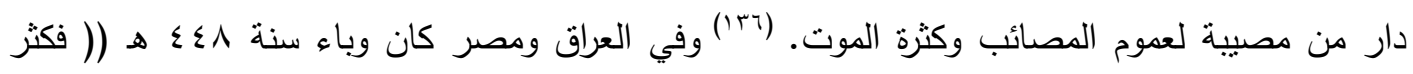

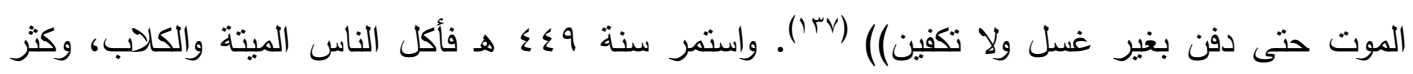


الموت فصار الدفن جماعيا(^"). وساد وباء عظيم سنة 79؛ هـ الجزيرة والعراق والثشام مات بسبيه الكثير

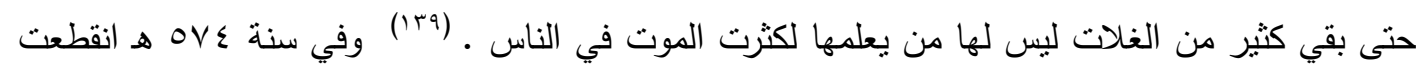

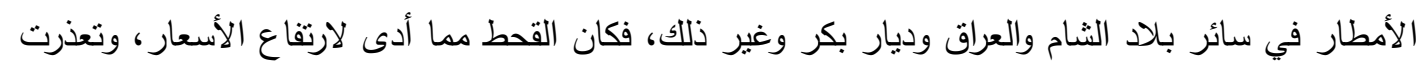

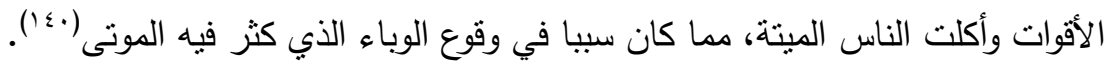

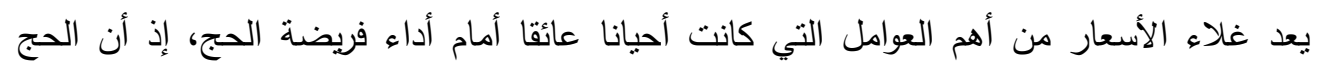
يتطلب نفقات استثنائية سواء لمتطلبات الحج أو لأهل الحاج في فترة غيابه عنهم التي ريما نطول شهورا،

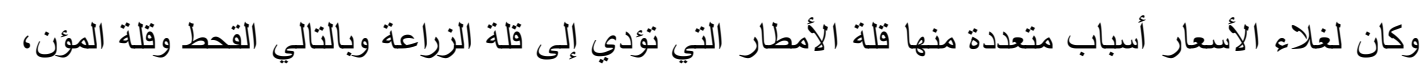

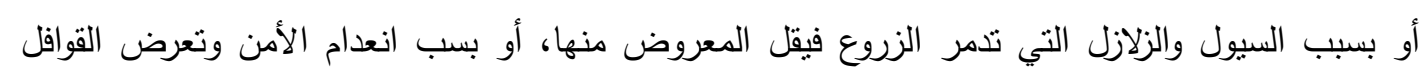
التجارية للسلب والنهب، أو بسبب الصراع السياسي والعسكري.

ففي سنة بوب هـ أرسل الخليفة العزيز الفاطمي إلى مكة جيثا لمحاصرة مكة، ومنعوا عنها الميرة، فغلت

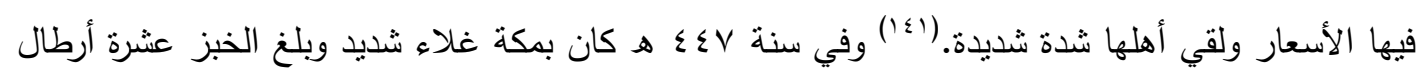

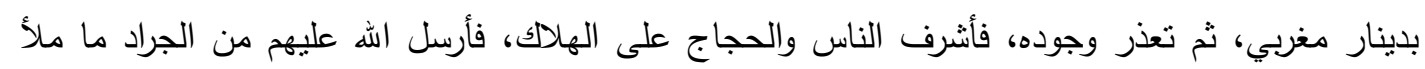

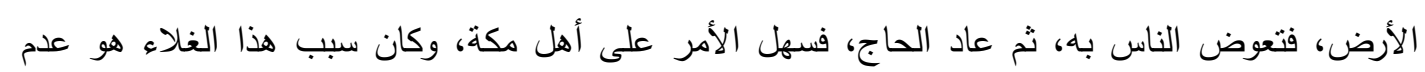

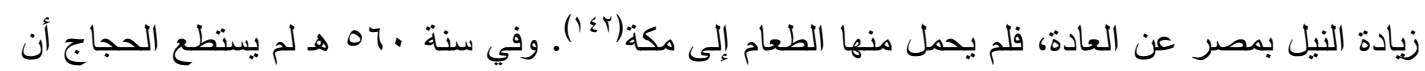

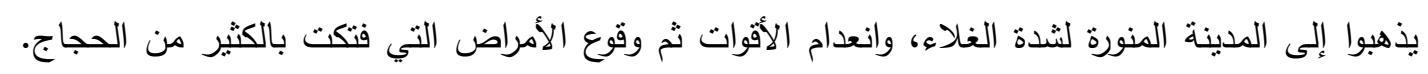

وكان لانقطاع الأمطار فترة طويلة، أن تتعدم الأقوات فترتفع الأسعار، وهذا يعني قلة القوت مما يؤدب

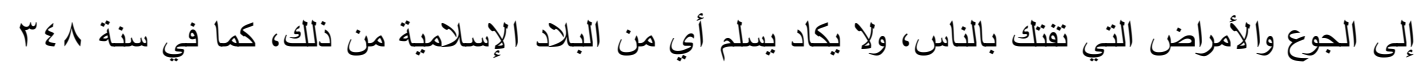

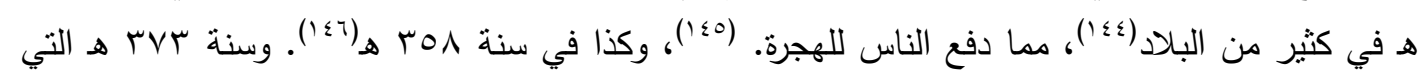

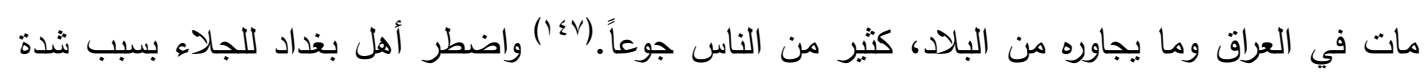

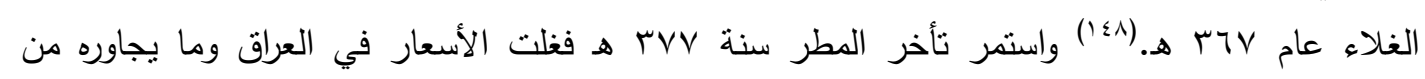

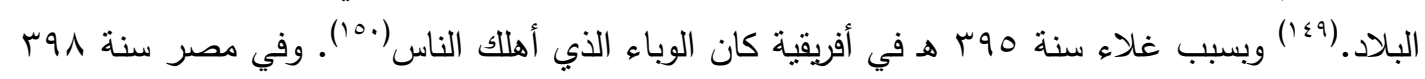

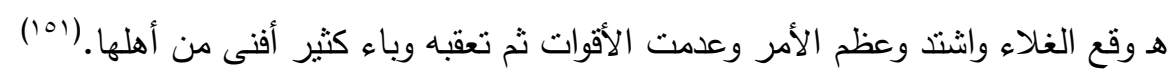




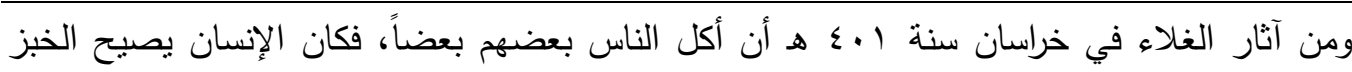

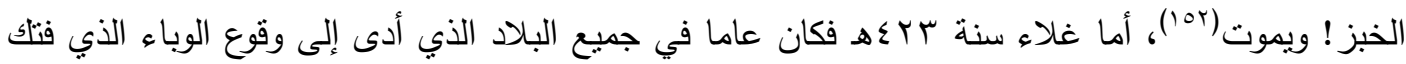

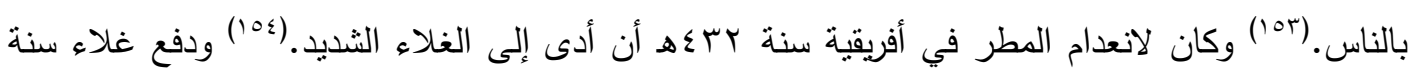

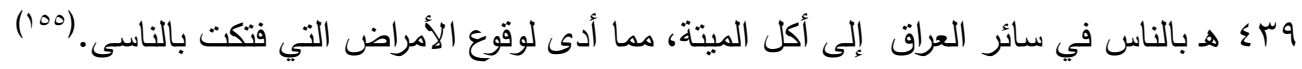

لقد كان بسبب انعدام الأمن وقطع الطرق في العراق سنة ^ـ؛ هـ أن ارتفعت الأسعار وتعذرت الأقوات

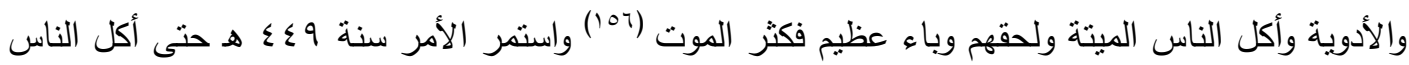
الميتة والكلاب وغيرها وكثر الوباء حتى عجز الناس عن دفن الموتى فكانوا يجعلون الجماعة في الحفيرة.

وفي خراسان أهلك البرد الزروع سنة بوح؛ هـ مما أدى إلى غلاء شديد دام سنتين، مما أدى إلى وباء

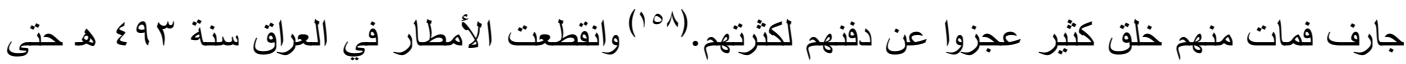

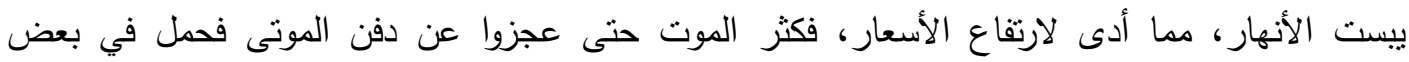

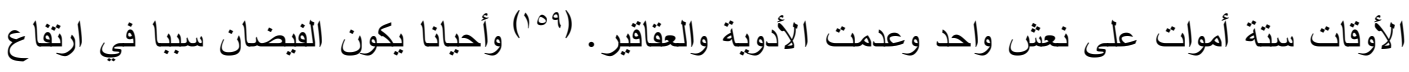

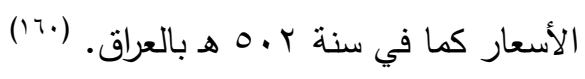

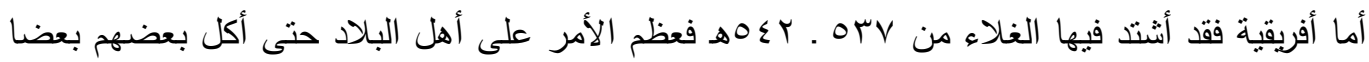

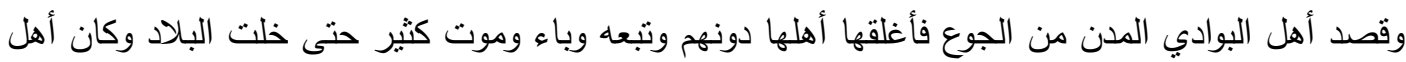
البيت الواحد لا يبقى منهم أحد وسار كثثر منهم إلى صقلية في طلب القوت ولقوا أمرا عظيماً. (ا7')

وبسبب دخول العساكر إلى بغداد سنة بـ0 هـ غلت الأسعار وتعذرت الأقوات، مما أدى إلى موت

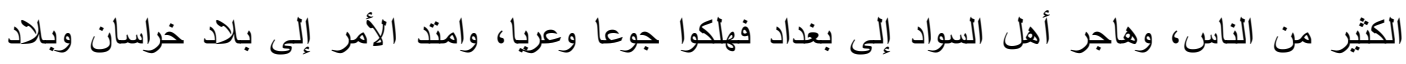

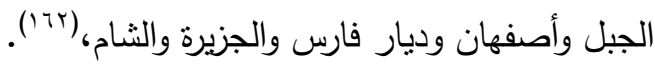

وكان عدم زيادة النيل سنة ه9 هـ سببا في اشتداد الغلاء فتعذرت الأقوات حتى أكل الناس الميتة وأكل

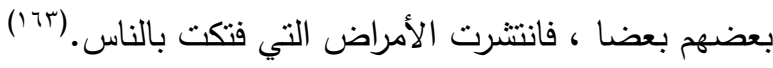




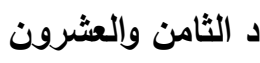

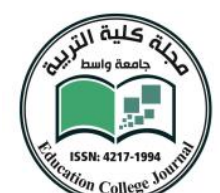

إن غلاء الأسعار وانعدام الأقوات ثم موت الكثير من الناس، من الأسباب التي حالت دون حج الكثير من

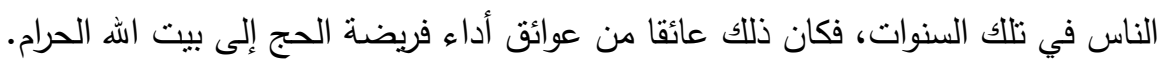




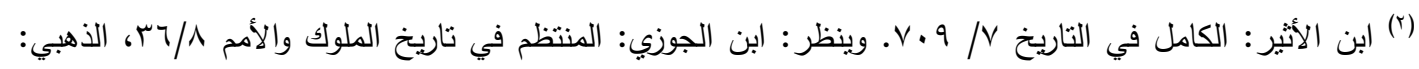

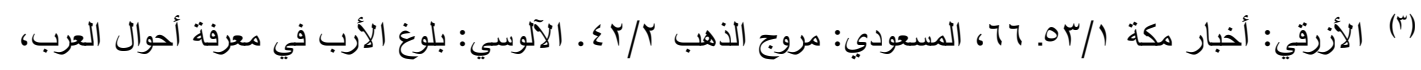

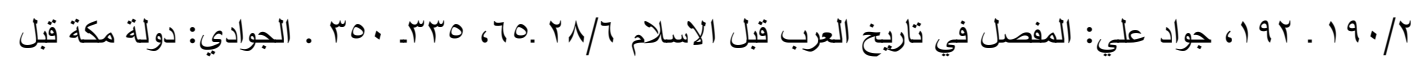

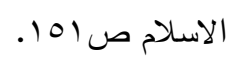

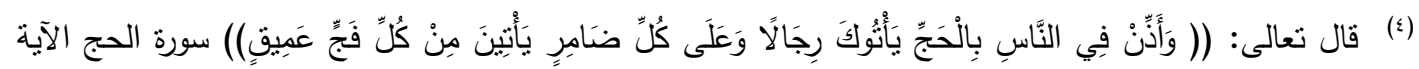

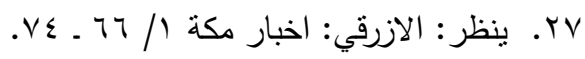

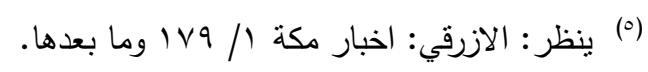

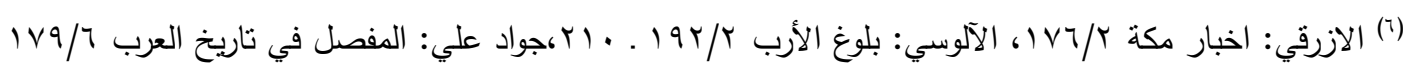

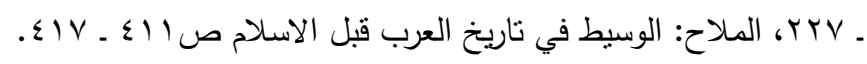

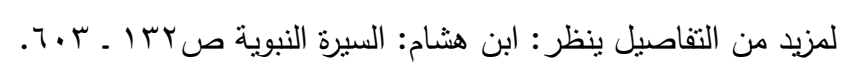

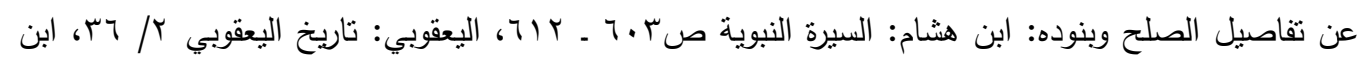

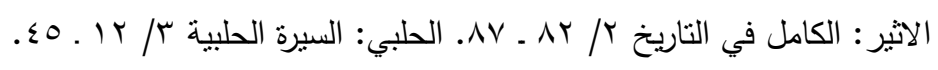

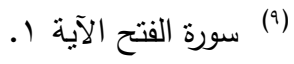

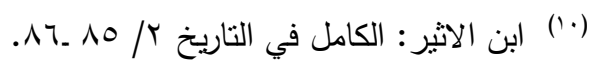

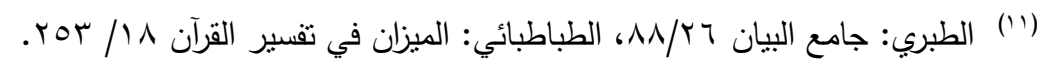

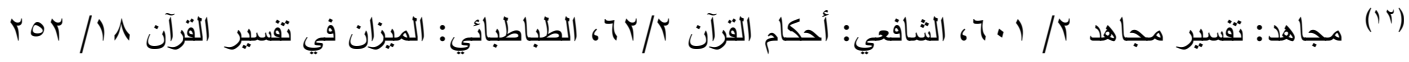

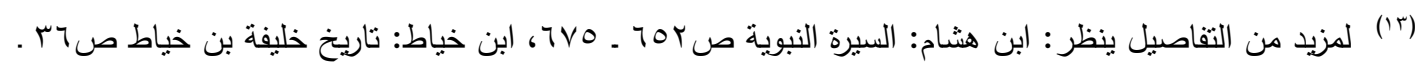

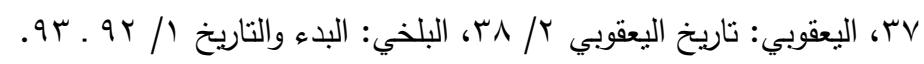

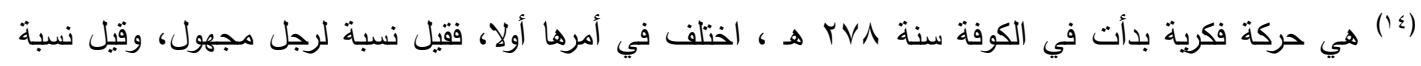

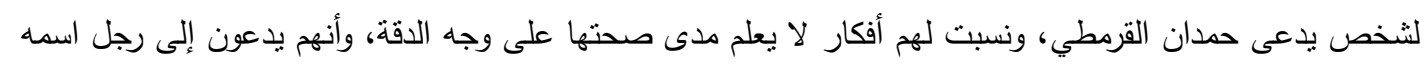

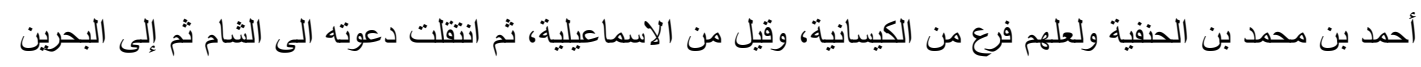

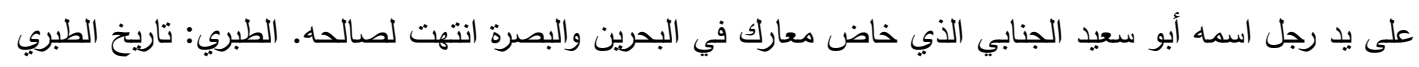




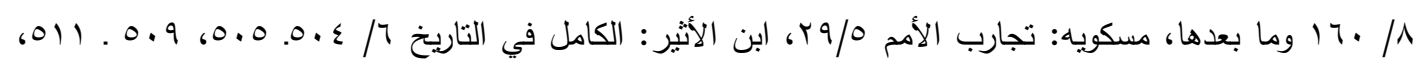

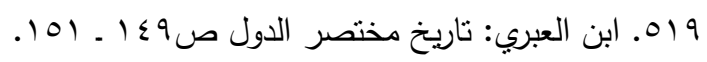

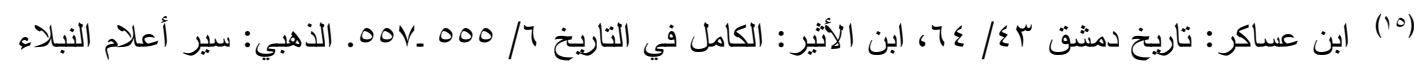
$. \Sigma \wedge \varepsilon / \mu$

(ז') هو أبو طاهر سليمان بن حسن القرمطي الجنابي، ملك البحرين، سار إلى مكة في سبع مئة فارس، فاستباح الحجيج كلهم في الحرم واقتلع الحجر الأسود، وردم زمزم بالقتلى، وقتل في سكك مكة وما حولها زهاء ثلاثثين ألفا،

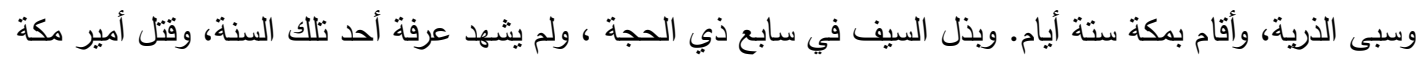
ابن محارب، وعرى البيت ، وأخذ بابه ، ورجع إلى بلاد هجر • لمزبد من التفاصيل ينظر : الذهبي: سبر أعلام النبلاء (1)

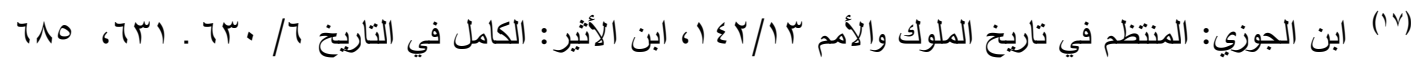

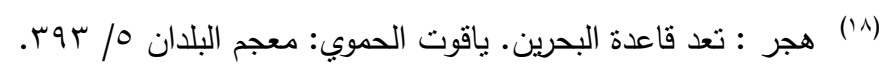

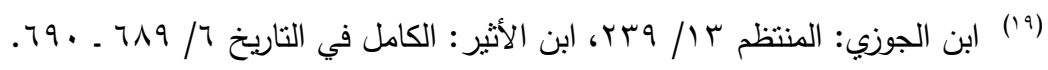

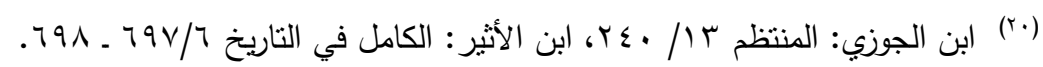

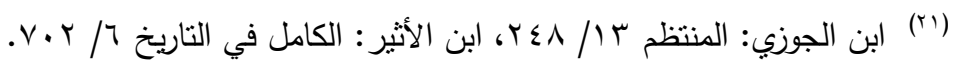

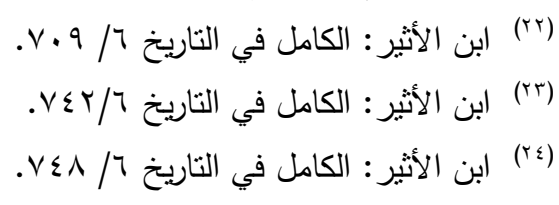

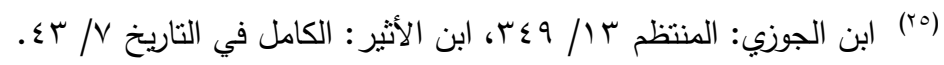

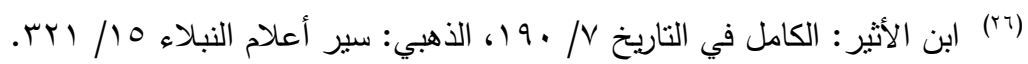

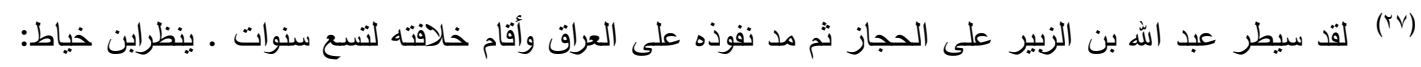

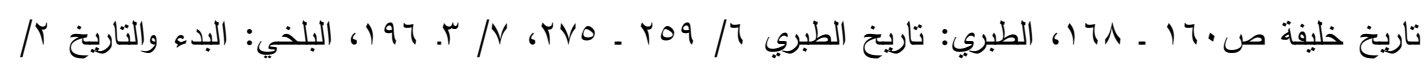

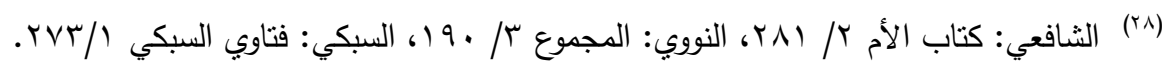

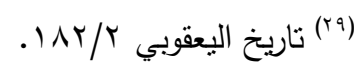

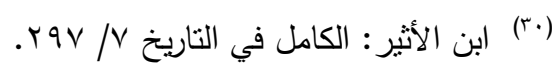

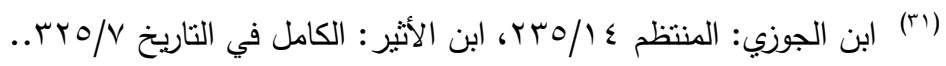




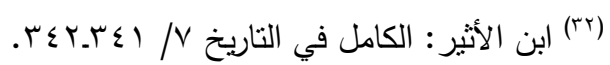

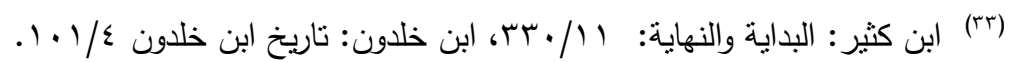

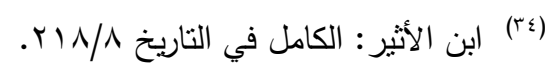

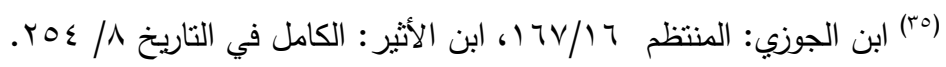

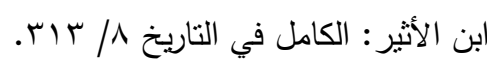

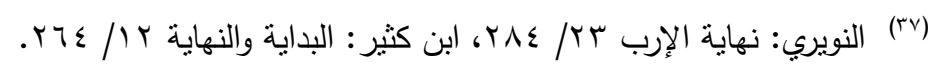

$$
\text { (r^) }
$$

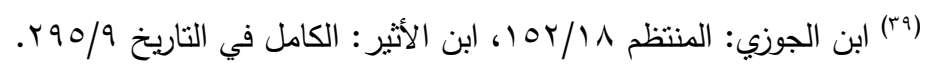

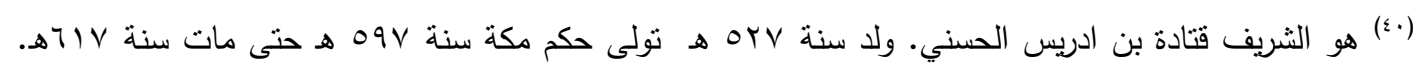

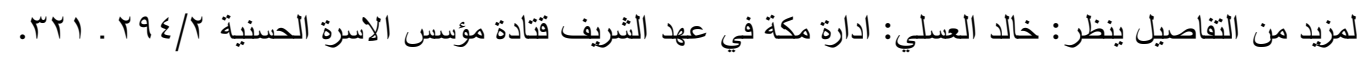

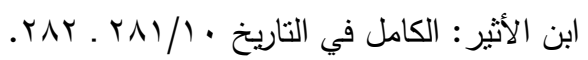

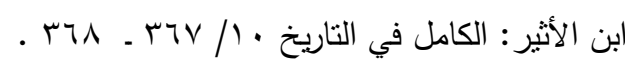

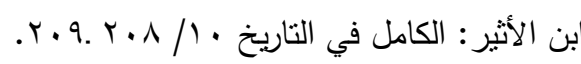

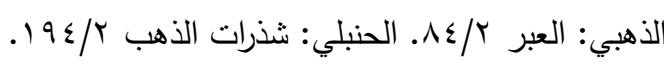

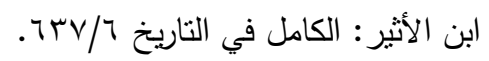

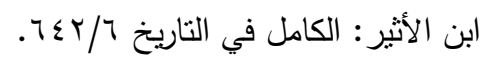

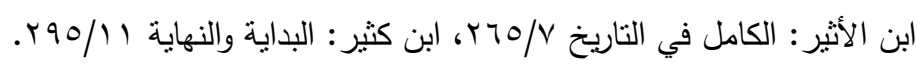

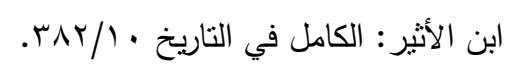

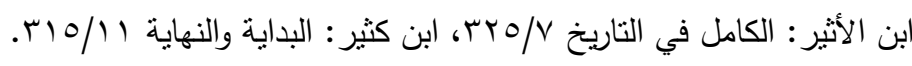

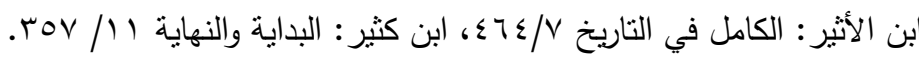

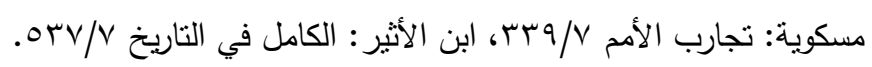

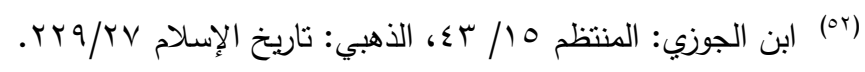

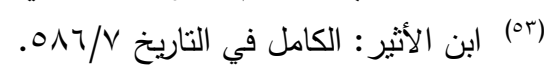

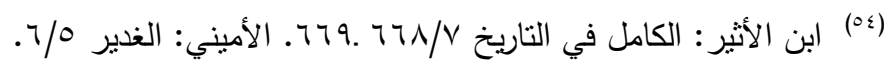

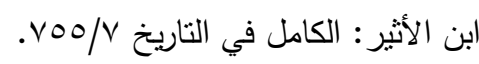

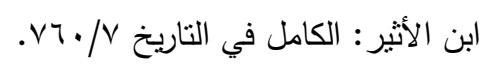

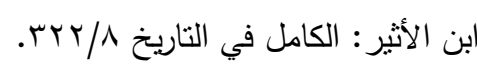

HוN 


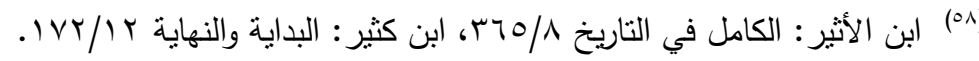

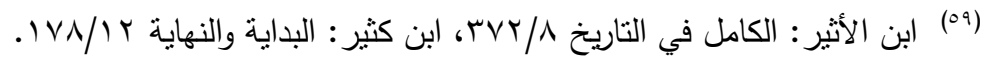

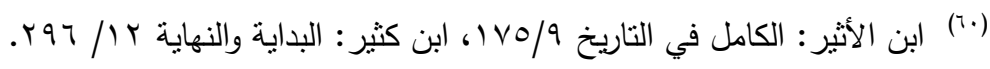

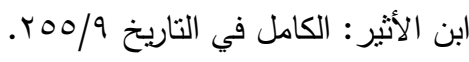

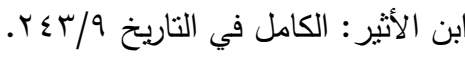

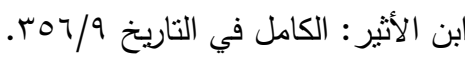

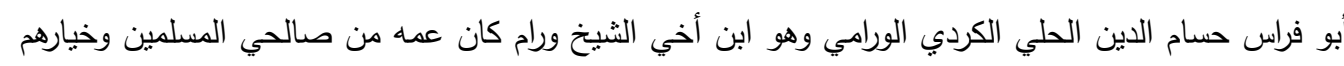

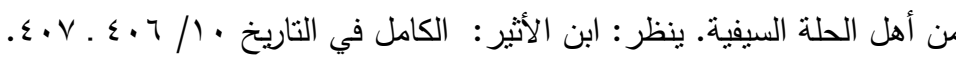

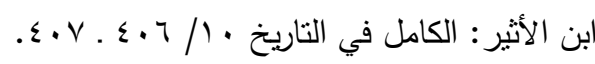

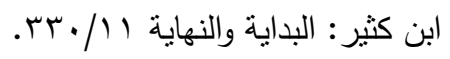

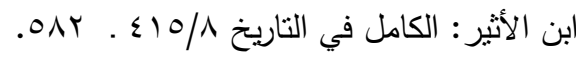

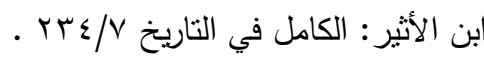

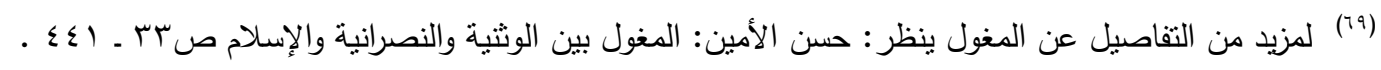

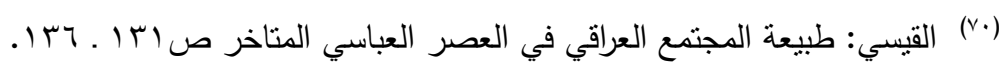

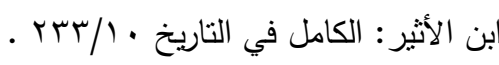

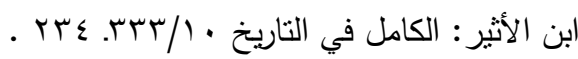

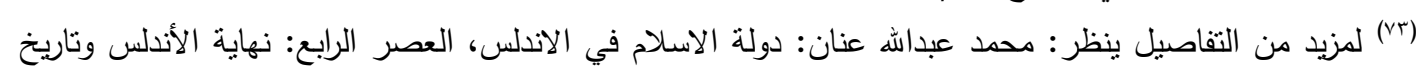

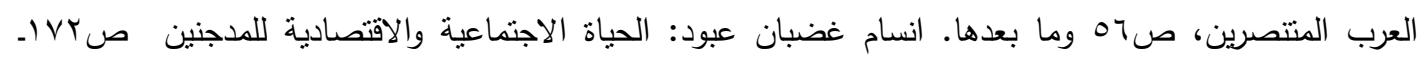
r.r (ء) لمزيد من التفاصيل ينظر: عنان: دولة الاسلام في الاندلس، العصر الرابع: نهاية الأندلس وتاريخ العرب

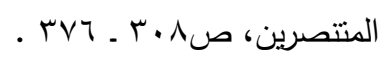

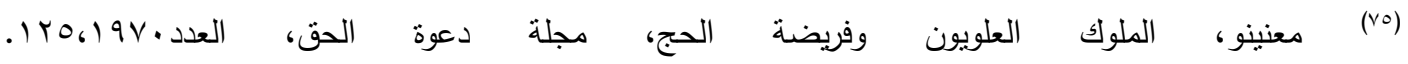
www.habous.gov.ma/daouat-alhaq/item/3056

$$
\begin{aligned}
& \text { (الريشهري: الحج والعمرة في الكتاب والسنة صع } 9 \text { (vi) }
\end{aligned}
$$

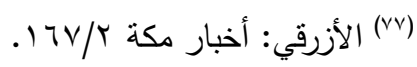


(ㅅ)

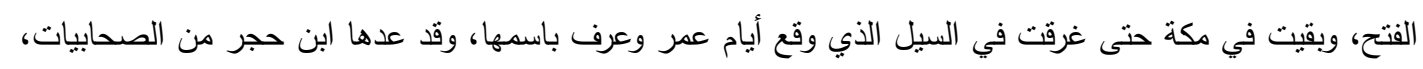

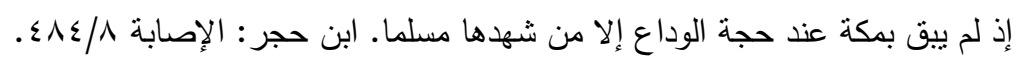

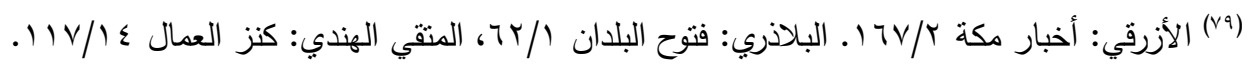

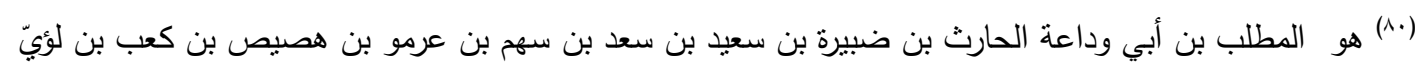

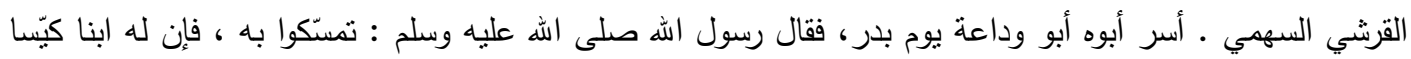

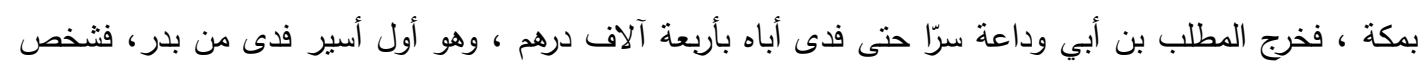

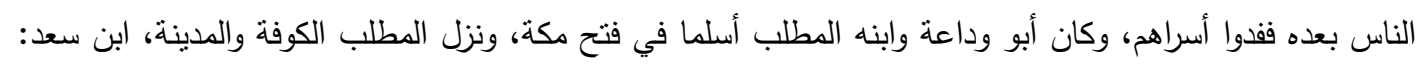

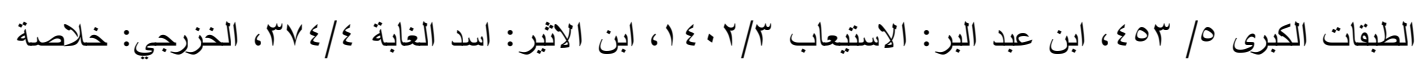
تذهيب تهذيب الكمال صو الطون.

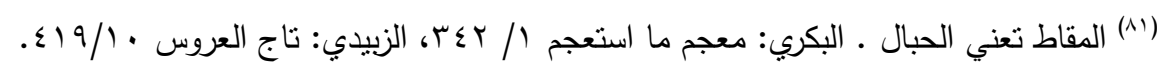

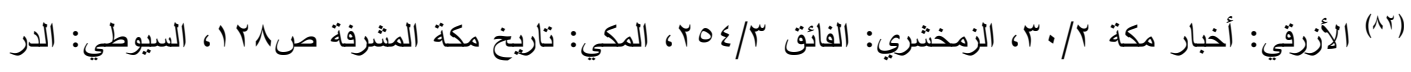

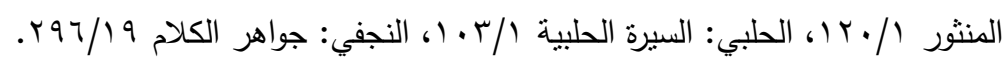

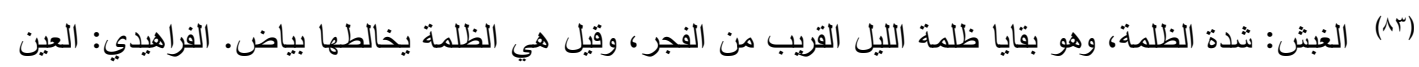

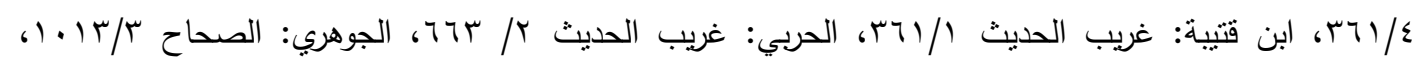

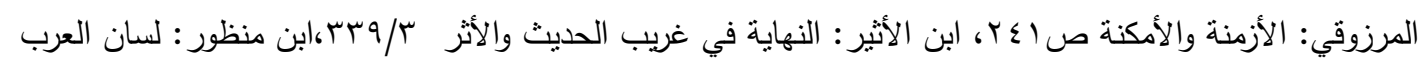
TrT/4

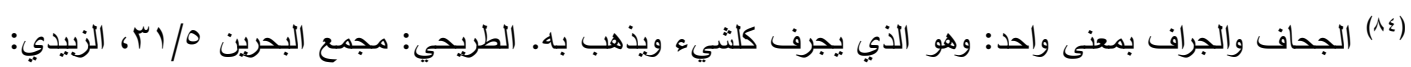

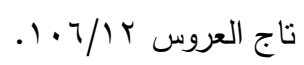

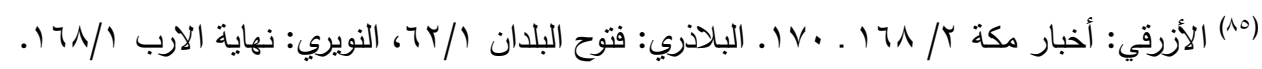

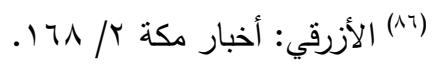

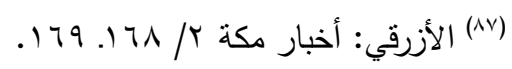

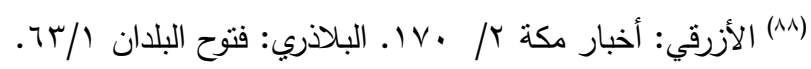

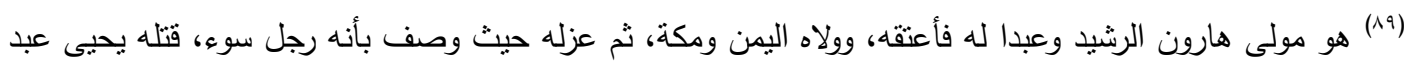

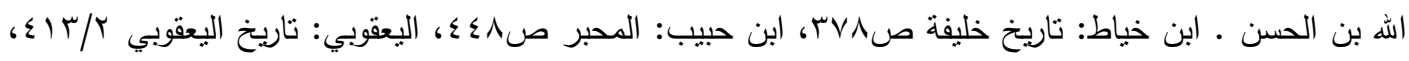

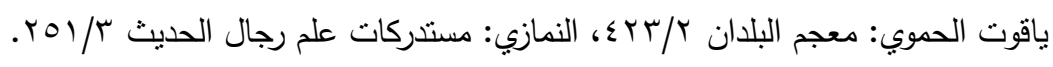

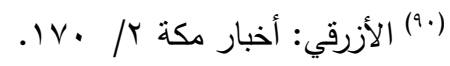

rT. 
(19) هو يزيد بن محمد بن حنظلة المخزومي، استخلفه حمدون بن علي بن ماهان والي مكة للمأمون، على مكة وخرج

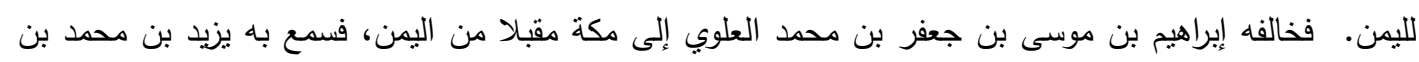

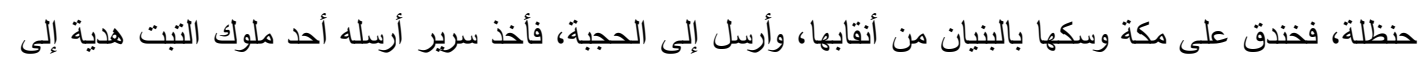

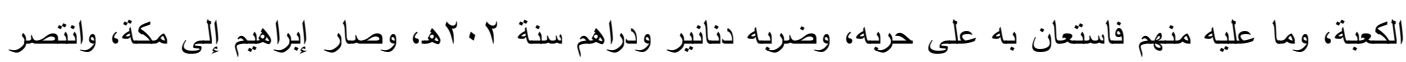

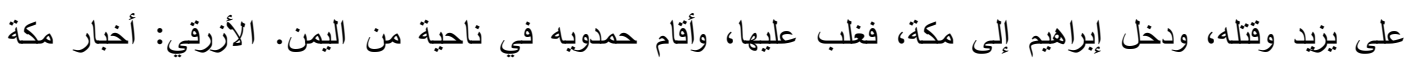

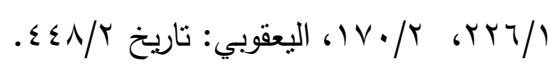

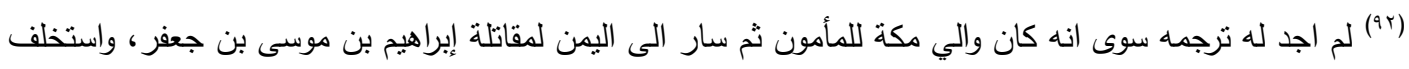

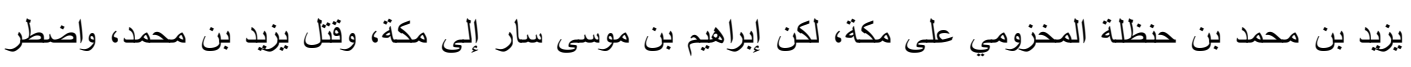

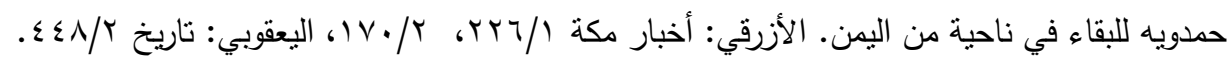

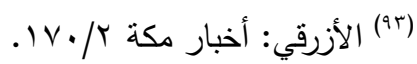

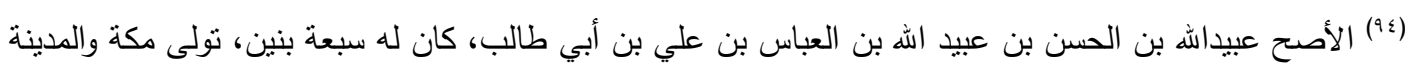

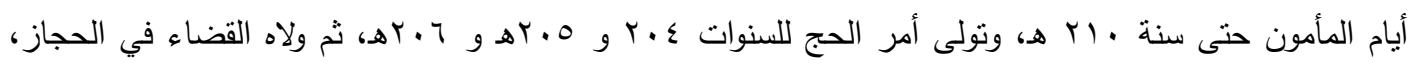

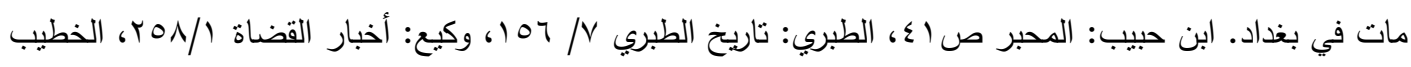

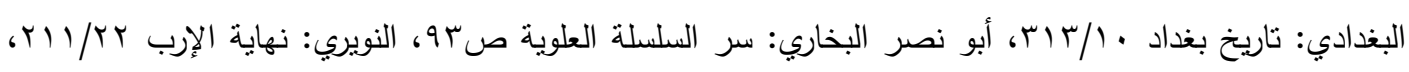

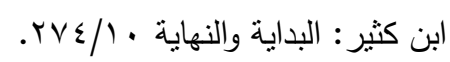

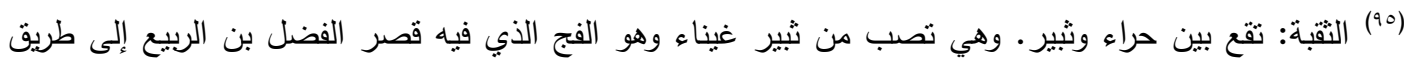

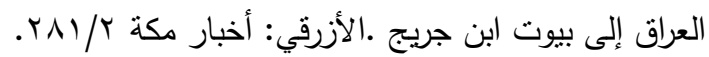

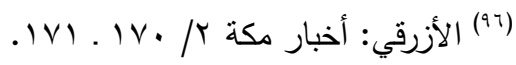

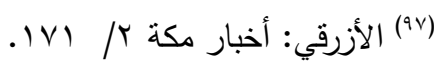

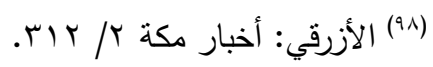

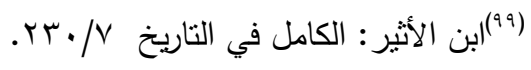

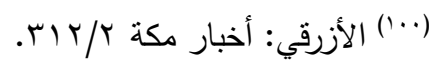

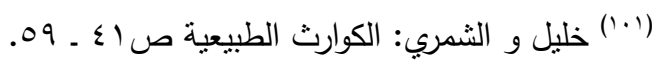

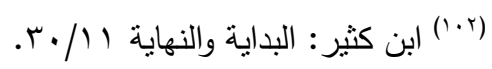

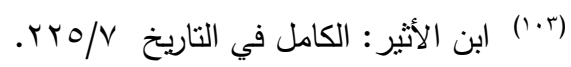

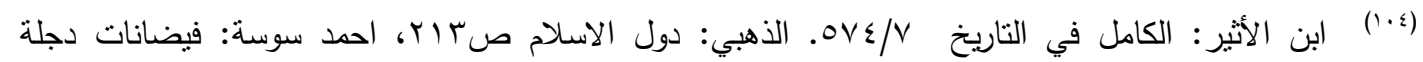
ص ص 


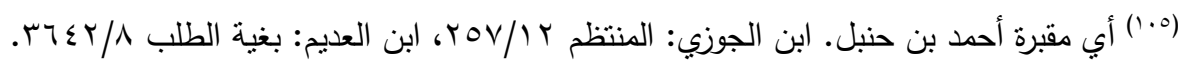

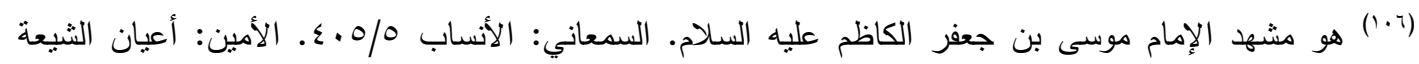
$. r 94 / 4$

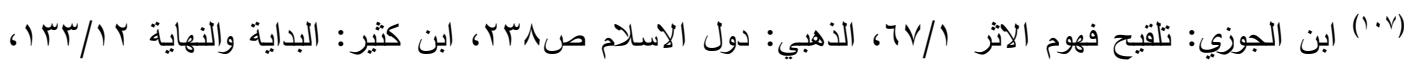

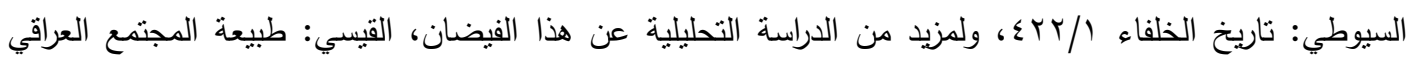

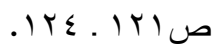

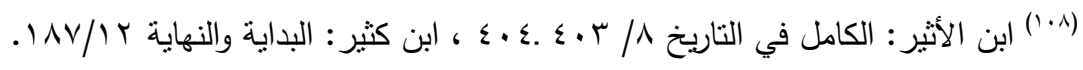

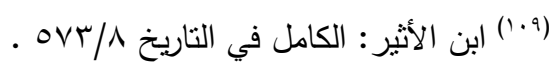

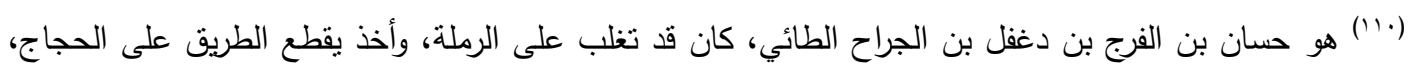

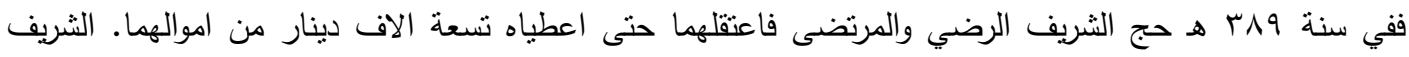

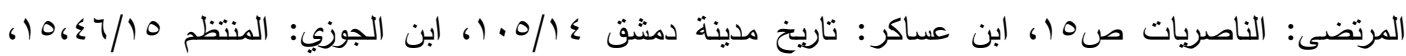

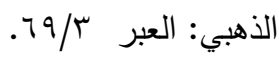

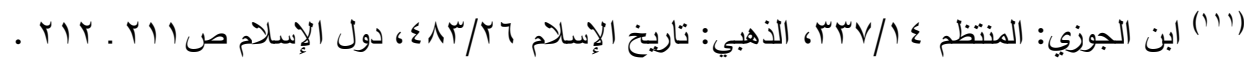

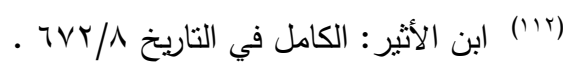

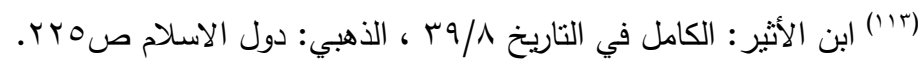

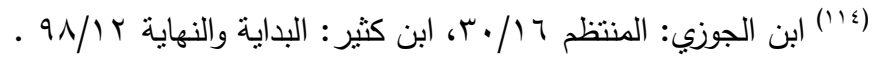

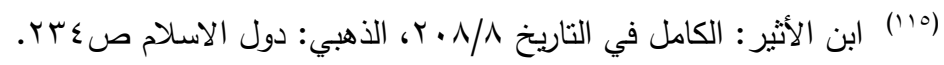

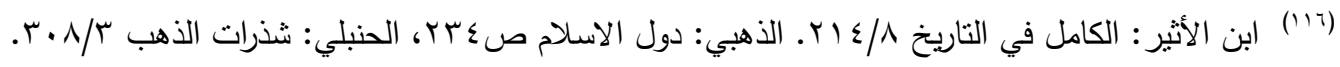

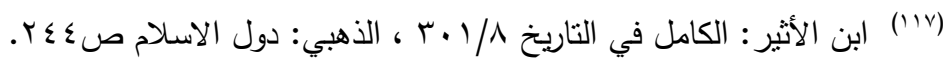

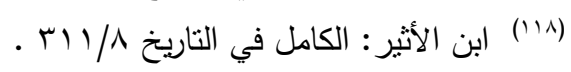

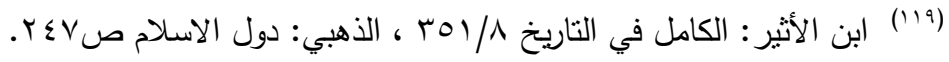

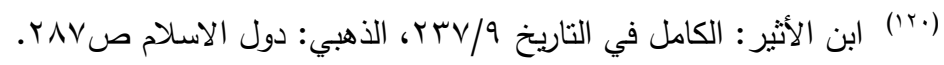

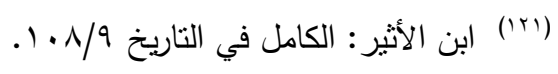

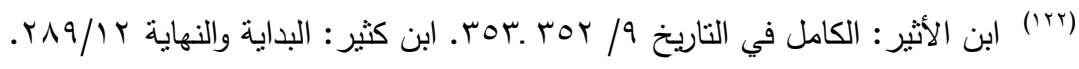

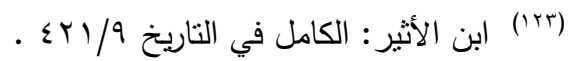

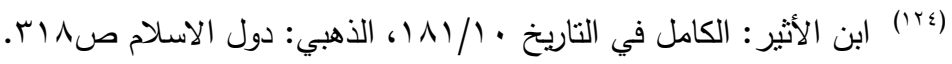

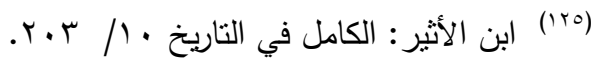




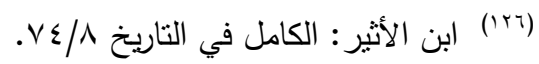

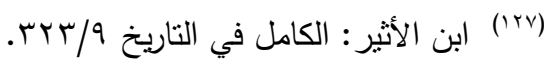

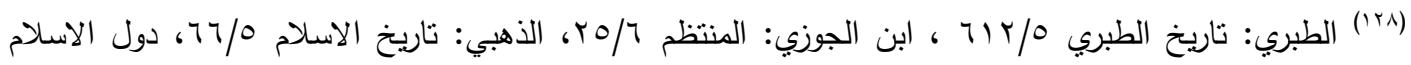

$$
\begin{aligned}
& \text { صז؟. }
\end{aligned}
$$

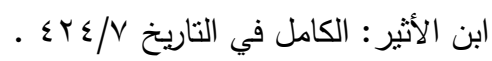

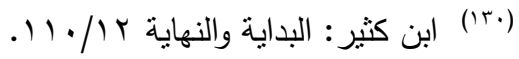

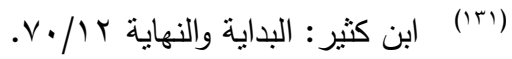

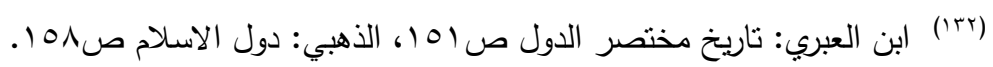

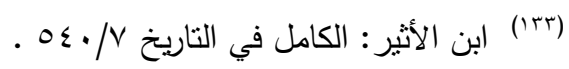

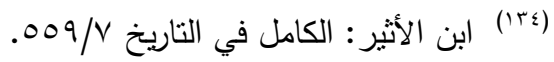

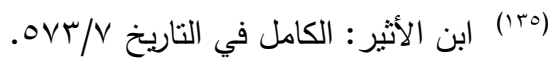

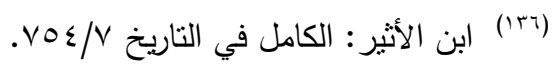

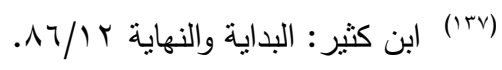

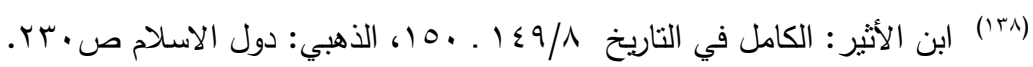

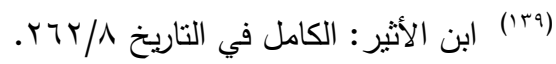

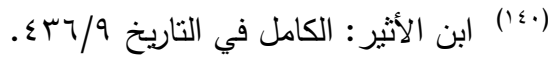

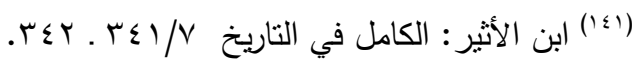

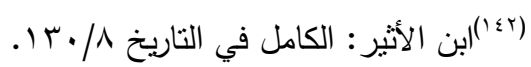

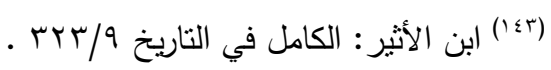

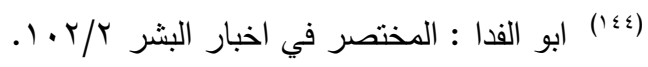

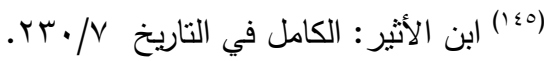

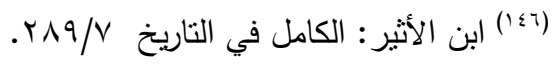

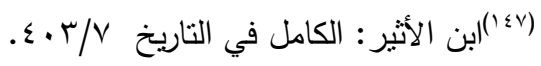

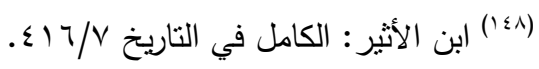

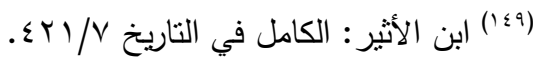

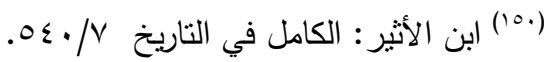

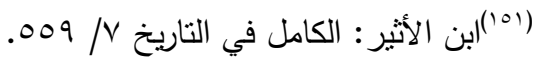




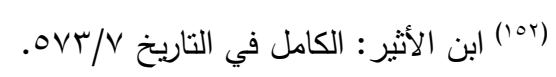

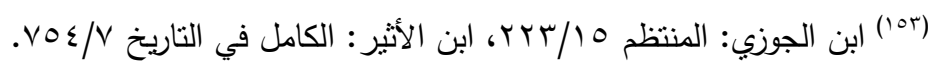

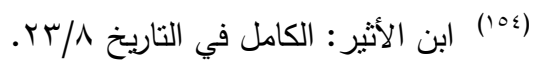

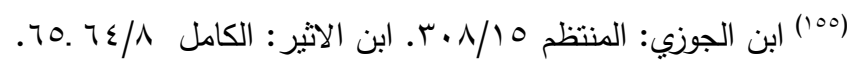

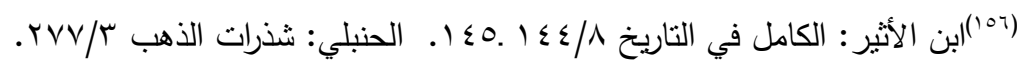

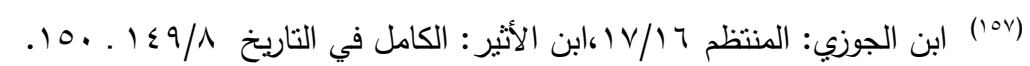

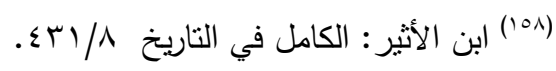

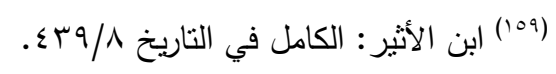

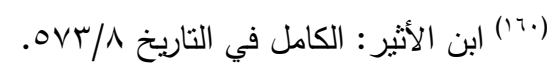

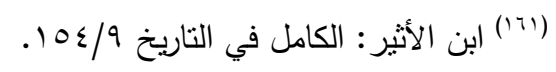

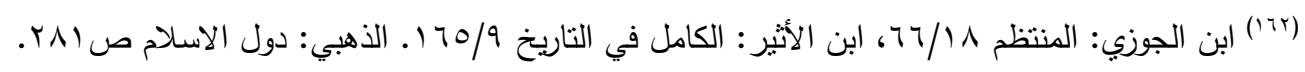

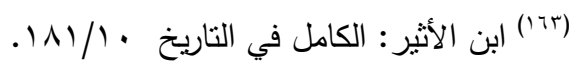




\section{فهر المصادر والمراجع}

$$
\text { القوآن الكريم الكصادر الأولية }
$$

ابن الأثير: عز الدين أبو الحسن علي بن أبي الكرم ت . بآ هـ.

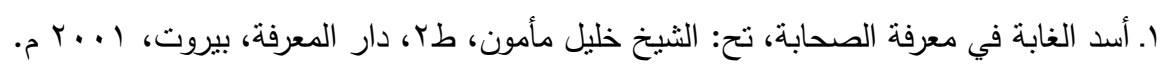

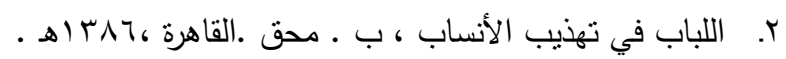

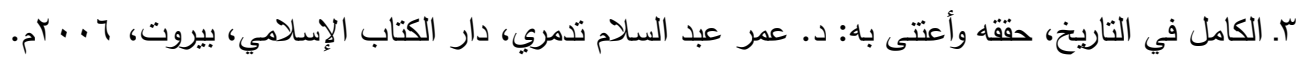

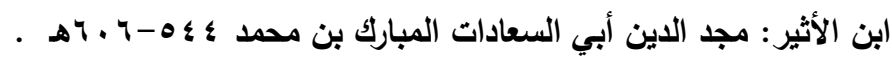

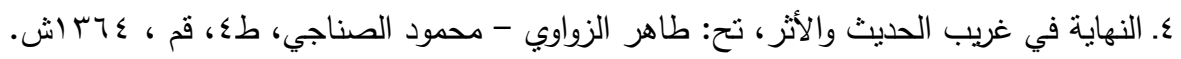

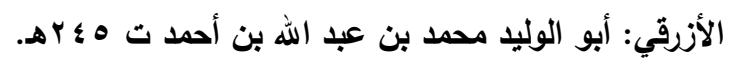

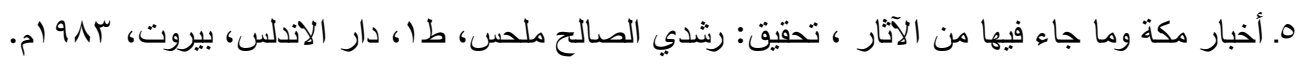

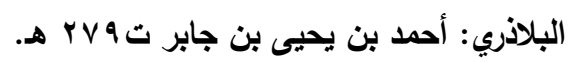

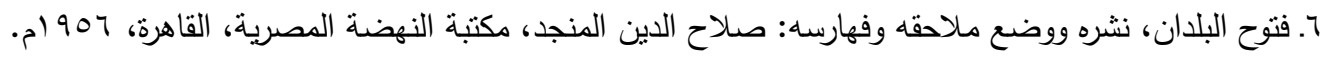

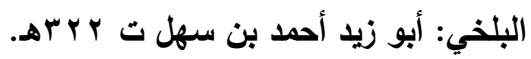

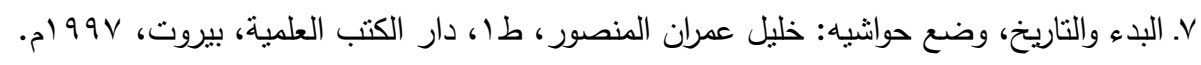

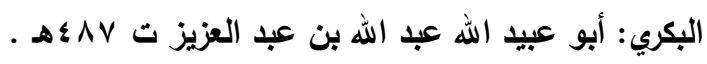

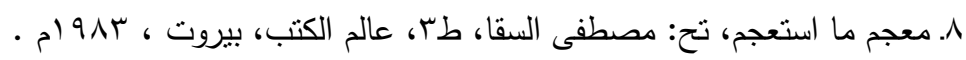

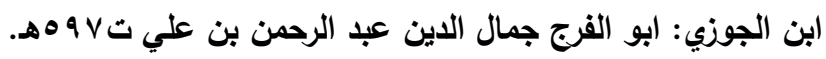

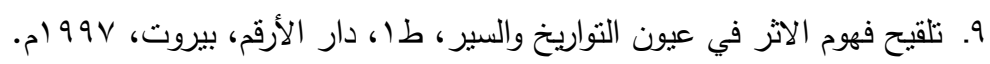

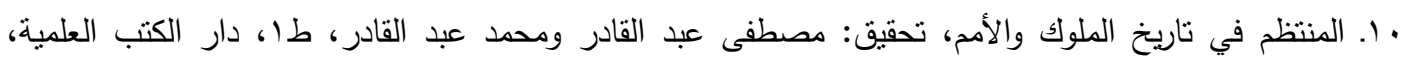

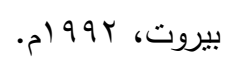

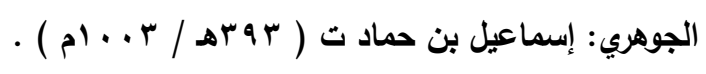

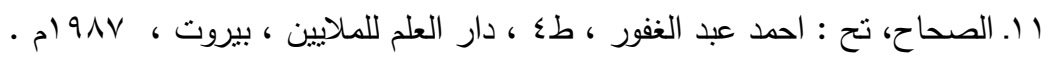

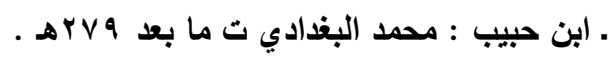

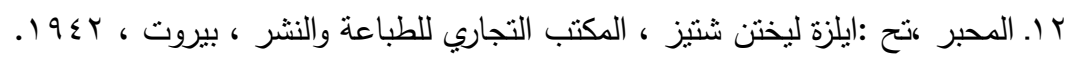

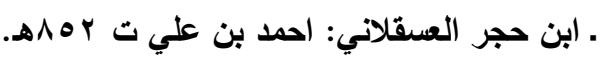

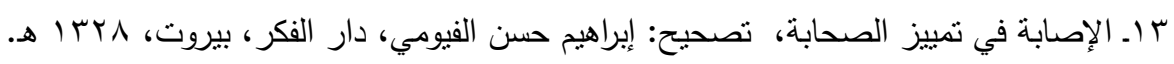
rro 


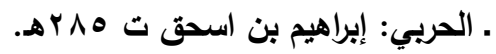

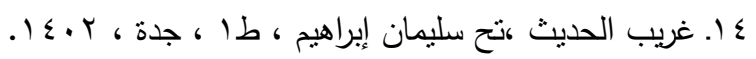

ـ الحلبي: أبو الفرج نور الاين علي بن إبراهيم الثافعي ت ؛ ؛ ـ 1 هـ.

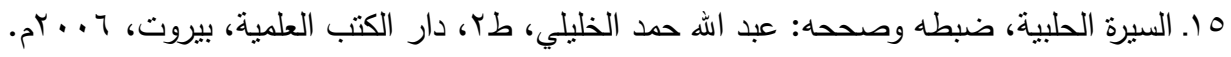

الحميري : محمد بن عبد المنعم ت أه

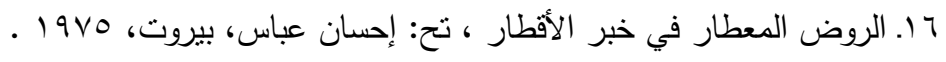

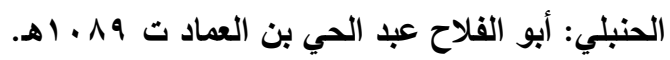

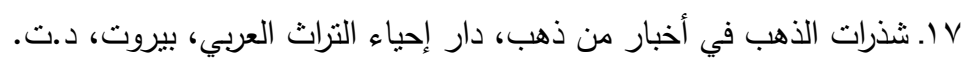

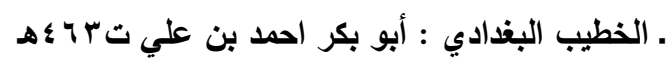

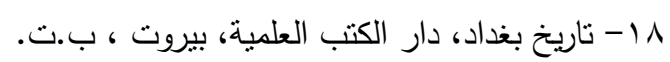

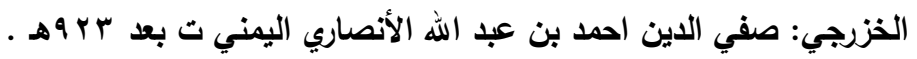

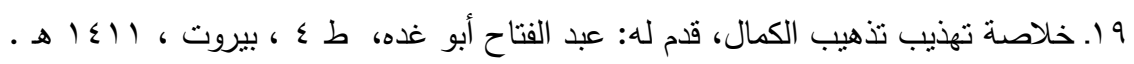

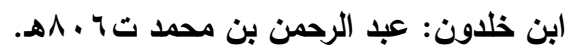

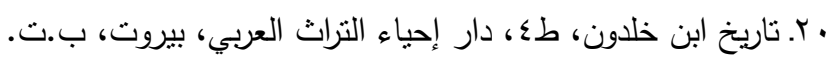

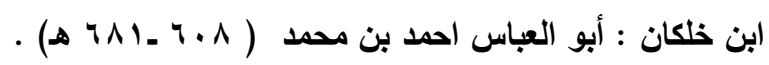

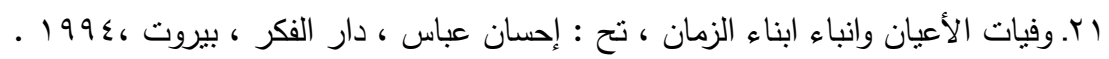

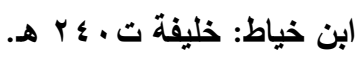

r.. تاريخ خليفة بن خياط، راجعه وضبطه: مصطفى نجيب فواز ، وحكمت فواز، طا، دار الكتب العلمية، بيروت،

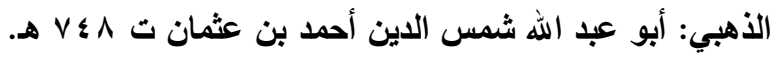

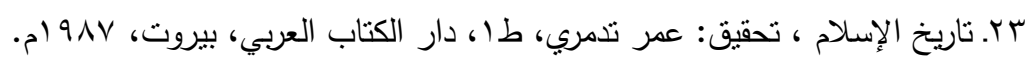

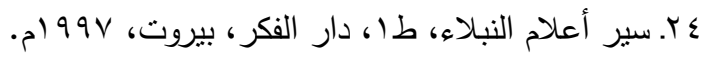

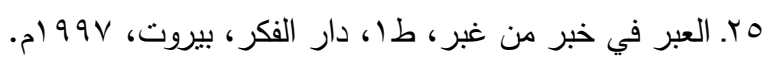

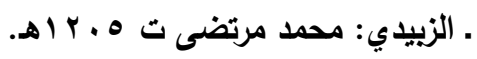

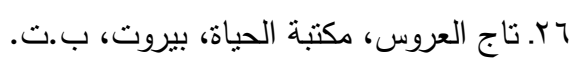

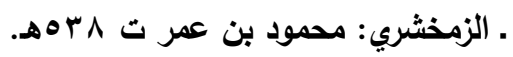

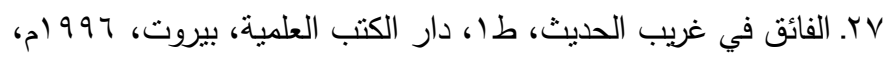
TYT 


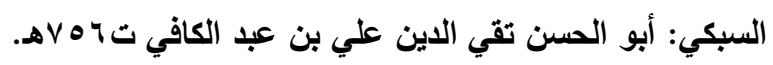

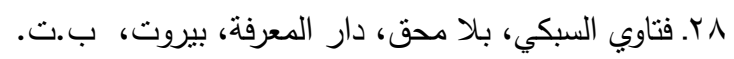

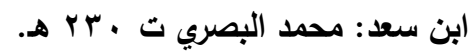

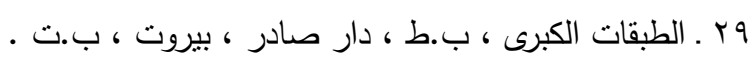

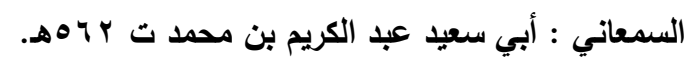

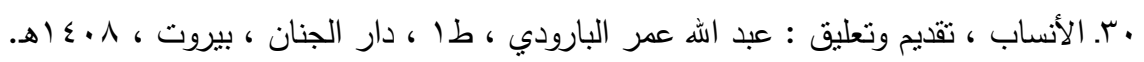

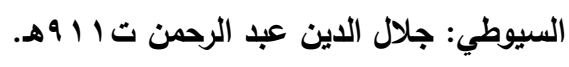

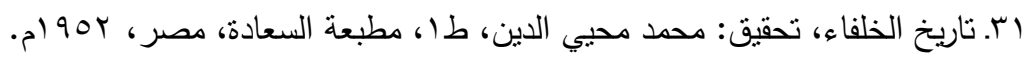

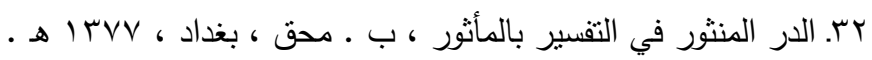

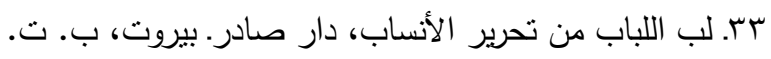

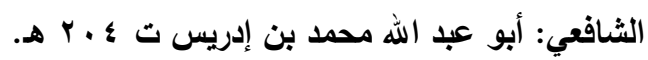

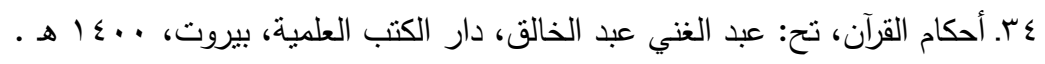

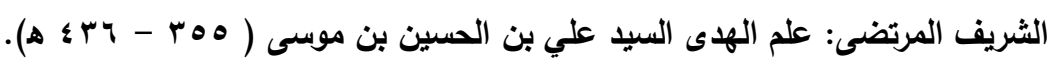
مr ـ مسائل الناصريات، لتحقيق : مركز البحوث والدراسات العلمية، الناشر : رابطة الثقافة والعلاقات الإسلامية،

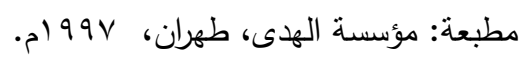

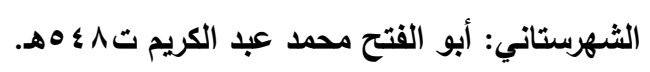

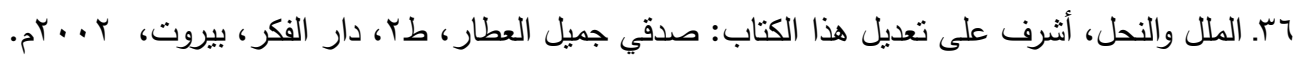

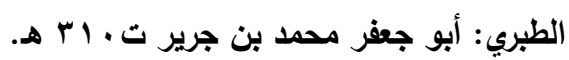

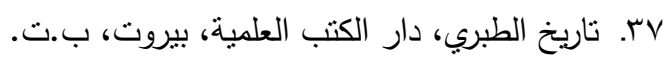

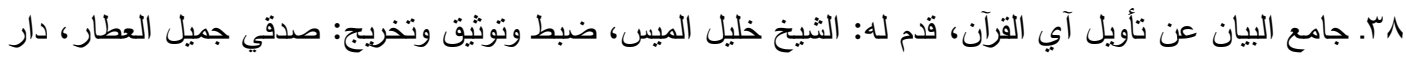

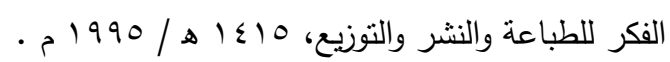

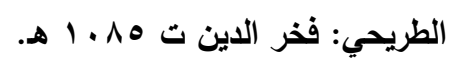

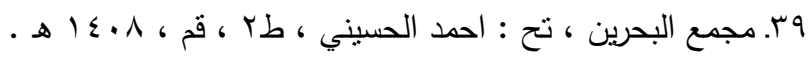

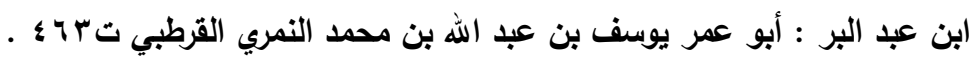

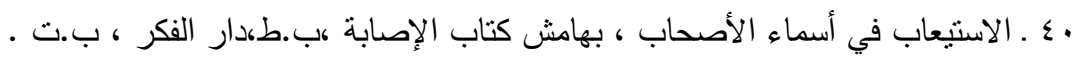

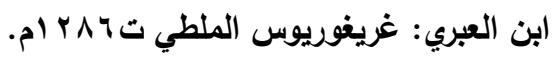

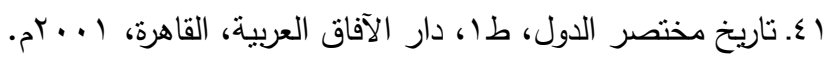
rrV 


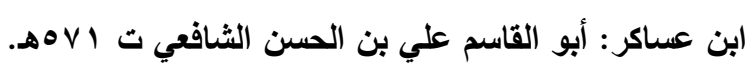

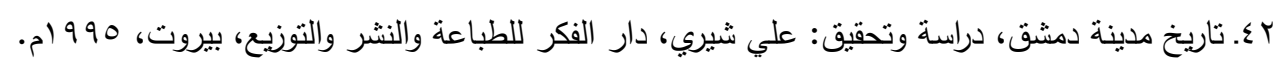

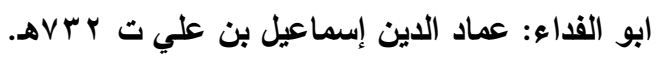

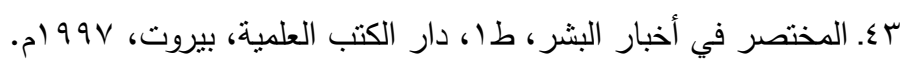

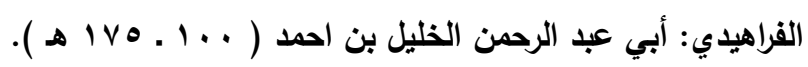

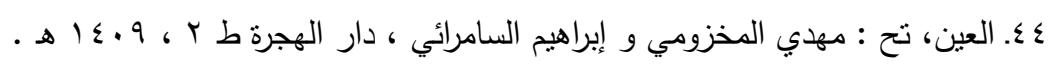

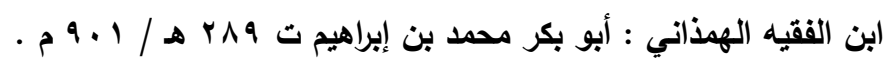

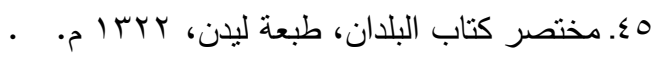

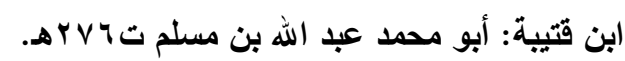

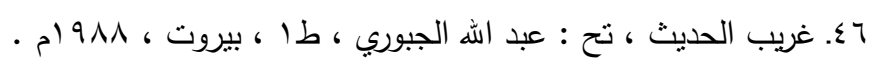

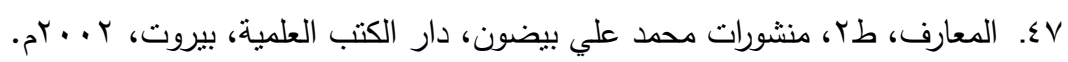

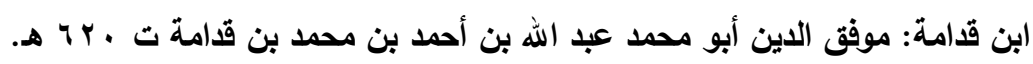

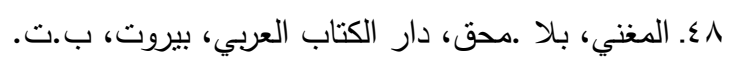

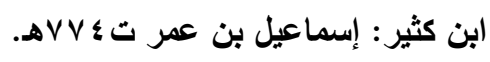

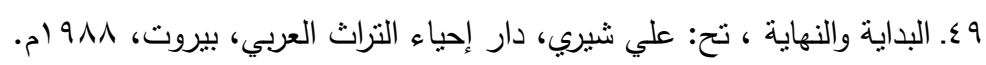

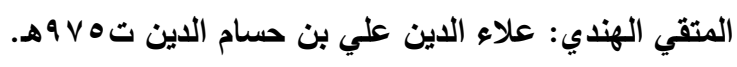

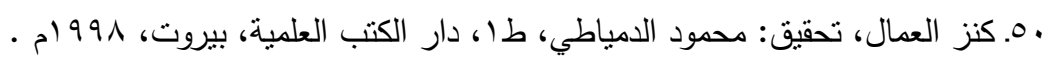

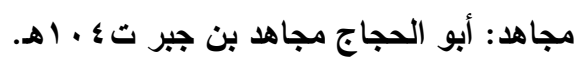

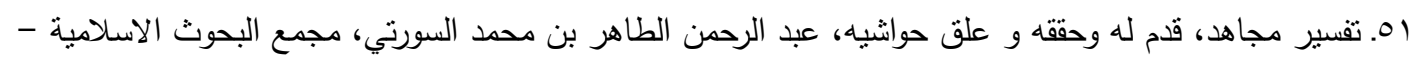

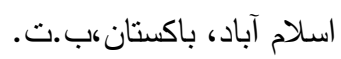

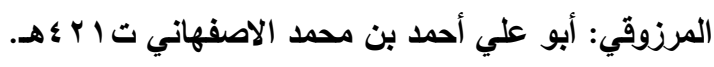

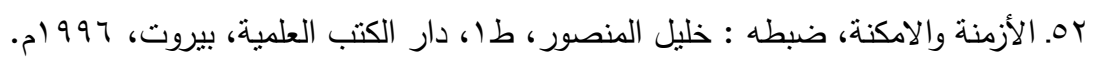

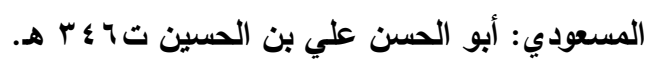

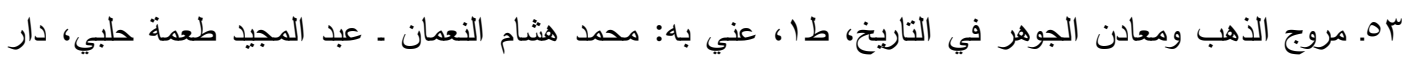

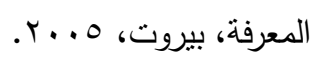

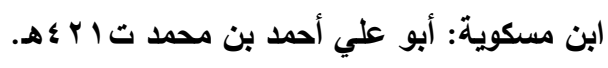

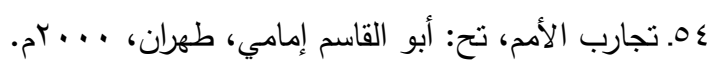




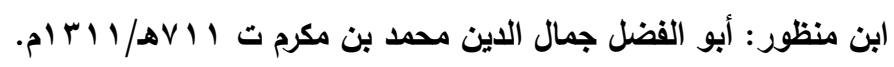

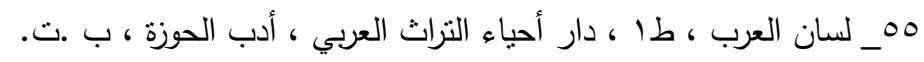

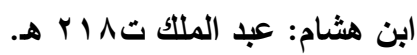

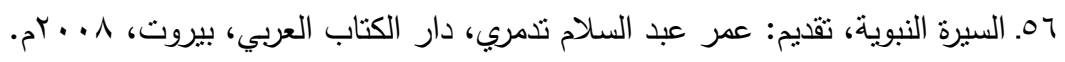

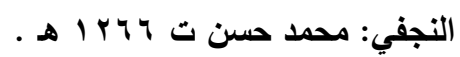

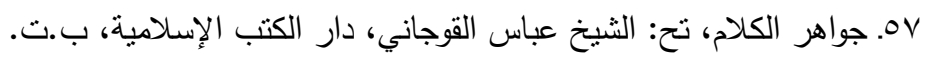

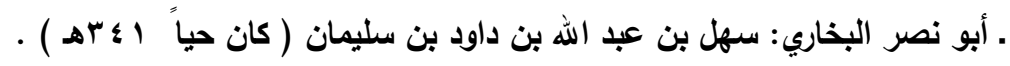

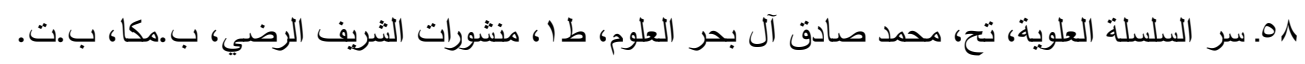

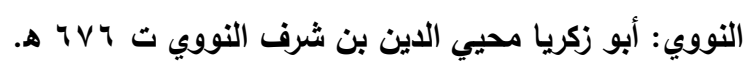

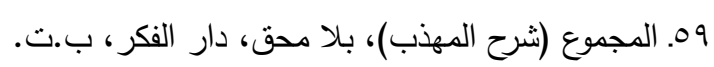

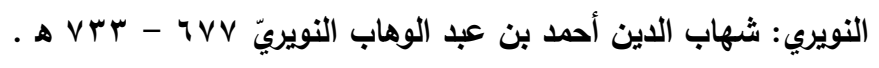

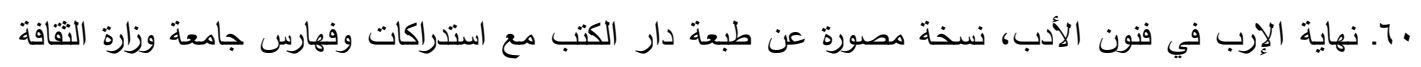

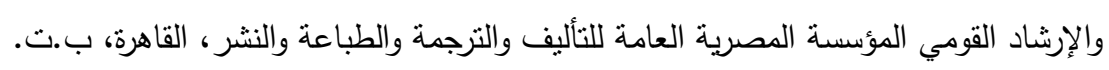

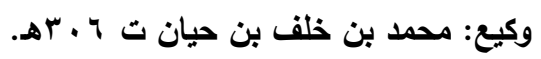

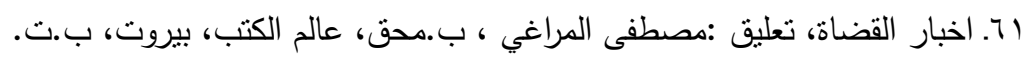

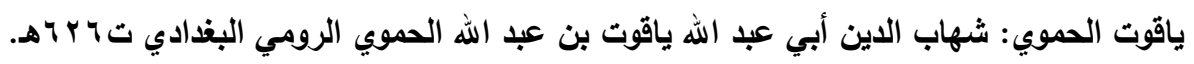

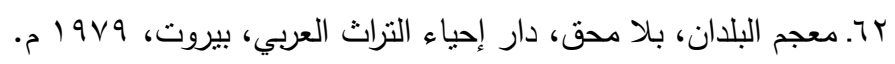

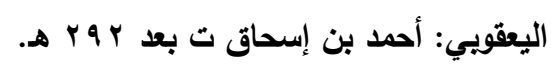

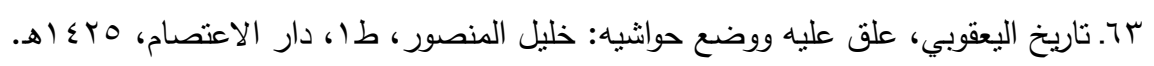

\section{المراجع الثانوية}

الالوسي: السيا محمود شكري البذادي ت ب ع با الهـ.

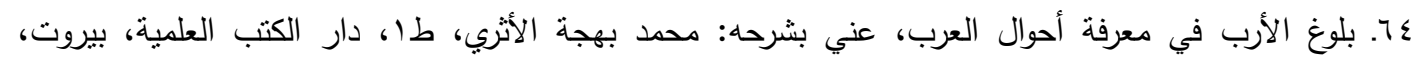

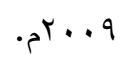
الأمين: حسن. ه7. المغول بين الوثثية والنصرانية والإسلام، دار التعارف للمطبوعات، بيروت، بـ 99 ام.

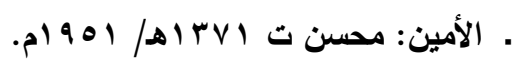


الأمين، أعيان الثيعة، تح : حسن الأمين ، بيروت، ب.ت.

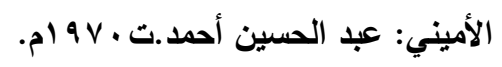

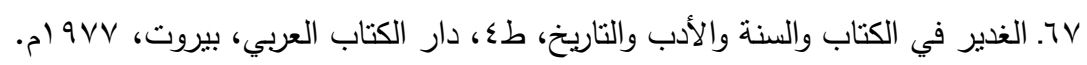

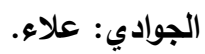

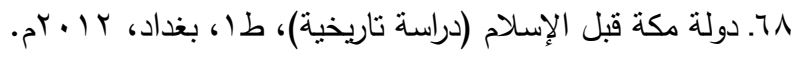
خليل: عادل إسماعيل ، و الثمري: دنيا عبد علي الطي

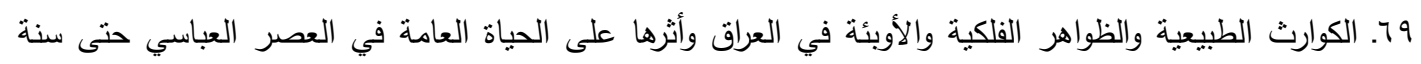

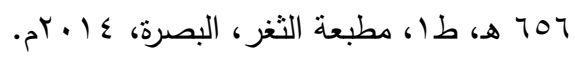
. الريشهري: محمد. • v . الحج والعمرة في الكتاب والسنة، الطبعة الأولى، دار الحديث، ب.ت.

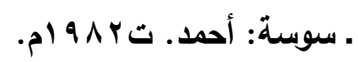

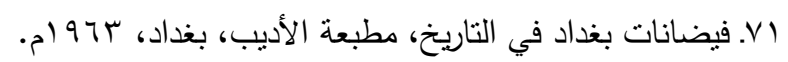

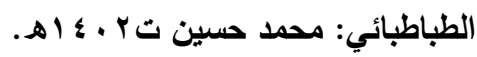

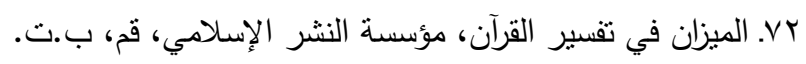
عبود: انسام غضبان. rr. الحياة الاجتماعية والاقتصادية للمدجنين في مدينة وشقة من خلا الوثائق العربية المحفوظة في كاتدرائية وشقة،

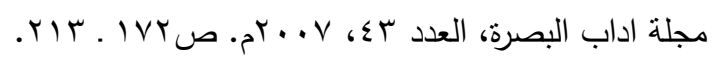

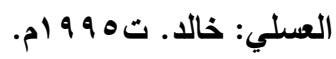

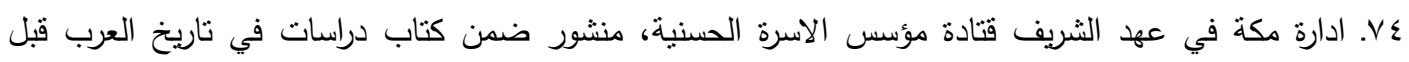

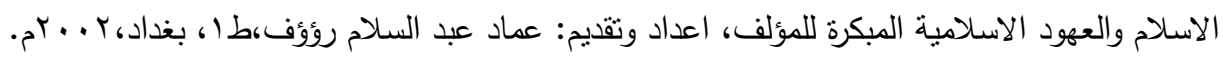

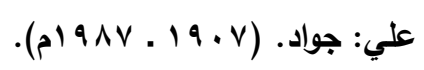

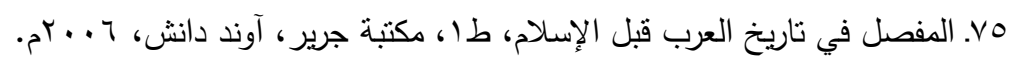

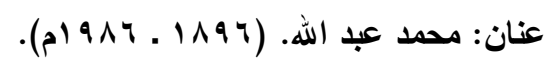
TوV. دولة الإسلام في الأندلس، العصر الرابع ( نهاية الأندلس وتاريخ العرب المتتصرة)، طع، مكتبة الخانجي، القاهرة، $.0199 \mathrm{~V}$ القيسي: حسين علي قيس محمد

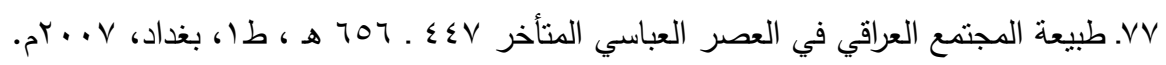
rr. 


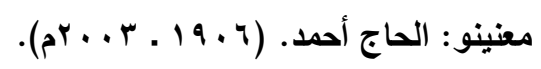

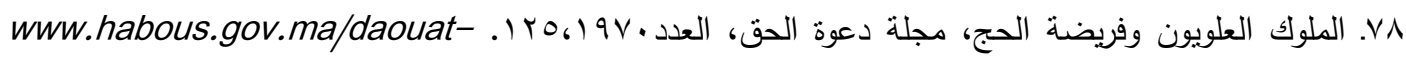
alhaq/item $/ 3056$

الملاح: هاشم يحيى.

9v. الوسيط في تاريخ العرب قبل الإسلام، دار الكتب للطباعة والنشر، الموصل، ؟9 9 ام. 


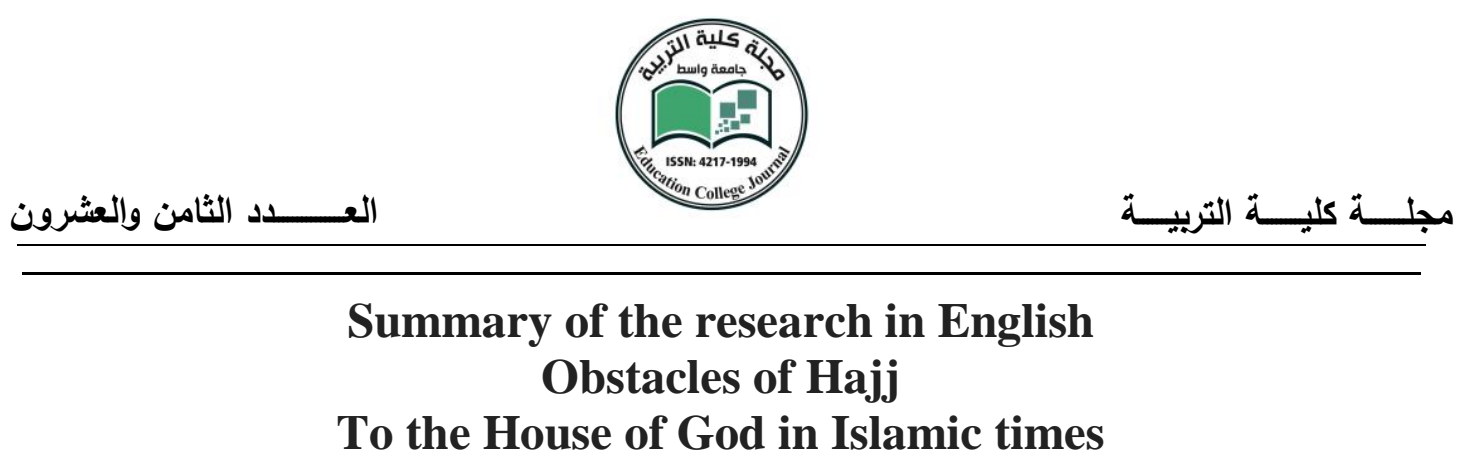

Prof. Dr Jawad Kadhem Al - Nasrallah

Dr Intisar Adnan Al-Awad

Muslims have been practicing the rituals of Hajj since its enactment in the time of the Prophet Muhammad, peace be upon him and his family, and Muslims were making strenuous efforts in order to perform his rituals.

Despite this great interest of Muslims, there are reasons that sometimes prevented the performance of pilgrimage to individuals or the people of a particular city or state, or completely prevented the performance of Hajj for that year.

These factors can be divided into three factors: First, the intellectual factors, such as the role of the polytheists in preventing the Prophet Muhammad and Muslims from performing it, and the actions taken by the Qaramites to prevent the performance of Hajj for many years, The state and the actions of the Arab tribes during the weakness of the state, where they cut off the road and carry out the looting and lootings of pilgrims, as well as the control of foreign forces on many countries and Islamic cities. There are natural factors such as floods, high winds, earthquakes, lightning, epidemics and high prices. 